\title{
UNIVERSITY INNOVATION, LOCAL ECONOMIC GROWTH, AND ENTREPRENEURSHIP
}

by

\author{
Naomi Hausman * \\ Harvard University
}

CES 12-10 June, 2012

The research program of the Center for Economic Studies (CES) produces a wide range of economic analyses to improve the statistical programs of the U.S. Census Bureau. Many of these analyses take the form of CES research papers. The papers have not undergone the review accorded Census Bureau publications and no endorsement should be inferred. Any opinions and conclusions expressed herein are those of the author(s) and do not necessarily represent the views of the U.S. Census Bureau. All results have been reviewed to ensure that no confidential information is disclosed. Republication in whole or part must be cleared with the authors.

To obtain information about the series, see www.census.gov/ces or contact C.J. Krizan, Editor, Discussion Papers, U.S. Census Bureau, Center for Economic Studies 2K130F, 4600 Silver Hill Road, Washington, DC 20233, CES.Papers.List@census.gov. 


\begin{abstract}
Universities, often situated at the center of innovative clusters, are believed to be important drivers of local economic growth. This paper identifies the extent to which U.S. universities stimulate nearby economic activity using the interaction of a national shock to the spread of innovation from universities - the Bayh-Dole Act of 1980 - with pre-determined variation both within a university in academic strengths and across universities in federal research funding. Using longitudinal establishment-level data from the Census, I find that longrun employment and payroll per worker around universities rise particularly rapidly after BayhDole in industries more closely related to local university innovative strengths. The impact of university innovation increases with geographic proximity to the university. Counties surrounding universities that received more pre-Bayh-Dole federal funding - particularly from the Department of Defense and the National Institutes of Health - experienced faster employment growth after the law. Entering establishments - in particular multi-unit firm expansions - over the period from 1977 to 1997 were especially important in generating long-run employment growth, while incumbents experienced modest declines, consistent with creative destruction. Suggestive of their complementarities with universities, large establishments contributed more substantially to the total 20-year growth effect than did small establishments.
\end{abstract}

*I am grateful to Ed Glaeser, Larry Katz, Josh Lerner, and Scott Stern for many helpful discussions. I also benefitted from conversations with Philippe Aghion, Pierre Azoulay, Jeff Clemens, Rebecca Diamond, Richard Freeman, Jeff Furman, Claudia Goldin, Joshua Gottlieb, Guido Imbens, Bill Kerr, Josh Mitchel, and Kelly Shue. I thank Crayton Scott Walker for assistance with geographical data. I acknowledge support from the Ewing Marion Kauffman Foundation and from the Center for American Political Studies at Harvard University. Any opinions and conclusions expressed herein are those of the author(s) and do not necessarily represent the views of the U.S. Census Bureau. All results have been reviewed to ensure that no confidential information is disclosed. 


\section{Introduction}

What is the effect of universities on neighboring industry? Many of the most innovative and entrepreneurial places in the United States cluster around research universities, such as Silicon Valley around Stanford and Boston's Route 128 corridor around Harvard Medical School and MIT. Such agglomeration of industrial activity may arise for a number of reasons, including shared inputs, local natural advantages, skilled labor pooling, and, importantly, knowledge spillovers (Marshall (1890); Krugman (1991)). Proximity facilitates increased interaction between people and speedy flow of ideas, compounding the positive externalities of knowledge production and encouraging locally concentrated growth (Jacobs (1969) ; Lucas (1988)). Universities and research hospitals - important generators of new ideas and relatively disposed towards openness in discovery - are thus natural suspects as contributors to the local economy (Jaffe (1989); Furman and MacGarvie (2007)). But feedback effects from business activity and common underlying factors affecting both universities and industry make universities' influence difficult to measure. This paper uses a new strategy based on universities' technological strengths and a change in federal policy to identify effects of universities on the growth of neighboring industry.

Before 1980, universities lacked strong incentives to commercialize research; the federal government held rights to all intellectual property produced by universities in the course of federally funded research. ${ }^{1}$ But the December 1980 passage of the Bayh-Dole Act gave universities property rights to innovations developed under federal funding, and with these strong new incentives it opened a sea of patenting and licensing activity from universities as they developed infrastructure for technology transfer that they previously lacked (Henderson, Jaffe, and Trajtenberg (1998); Sampat et. al. (2003); AUTM Licensing Activity Survey). ${ }^{2}$ That this legal change fundamentally increased universities' connection to industry and induced greater spread of innovation from universities will help to identify their local effects. ${ }^{3}$

\footnotetext{
${ }^{1}$ Of course, some universities, especially public and land grant, were more practically oriented long before BayhDole (Mowery et. al. 2004; Sampat 2006; Goldin and Katz 2008). Because they were so heavily funded by the states, they always faced incentives to be responsible to local industry. Even these institutions, however, tended to keep their commercial arms divorced from the university, administering patents through research foundations (like Wisconsin Alumni Research Foundation) or third parties such as the Research Corporation.

${ }^{2}$ New Congressional endorsement of the value of these activities to the economy may have also been important in changing the anti-commercialization sentiment harbored in many universities.

${ }^{3}$ There is some dispute over the degree to which Bayh-Dole altered research and commercialization practices in universities. Mowery and Ziedonis (2000) and Mowery et. al. (2001) find in case studies of three universities that Bayh-Dole had little impact on the content of research but substantial impact on marketing ef-
} 
My strategy interacts the law change with cross-sectional variation in the extent to which industries benefit from nearby university innovation. Because universities produce more innovation - as measured by patents - in some technological areas than in others, I am able to identify the industries surrounding each university that are most likely to benefit from this increased spread of innovation. The industry intensities provide variation both within university, between industries, and between universities due to their different industrial mixes. This type of variation has the advantage that I can hold a geographical location fixed and identify an effect off of cross-industry differences in the intensity of field-specific innovation from the nearby university. I am further able to address the concern that universities may simply innovate in the nation's most quickly growing industries, such as biotech in the late 1980s and early 1990s, by controlling for nationwide changes in industry performance.

A natural additional test stems from the fact that, because Bayh-Dole affected federally funded inventions, universities receiving more federal funding before the law was passed were effectively more "treated" by the change: they had a larger affected research base from which the local economy could now benefit. I thus test whether areas grew differentially depending on the amount of federal research funding their local universities attracted in the several years before the Act was passed. I use detailed information on federal funding by agency and university to measure whether this effect holds for technological areas that might be especially closely tied to industry, such as those funded by the Department of Defense and the National Institutes of Health.

The Census Bureau's Longitudinal Business Database (LBD) enables me to measure outcomes for detailed industries at a high level of geographic specificity from 1977 to 1997. The detail of the data permits tight connections between university strengths and related industry employment, payroll, and establishment dynamics. Spanning twenty years, the data cover the passing of the Bayh-Dole Act and facilitate measurement of its long-run effects. This long horizon is crucial for understanding the substantial shift, marked by this policy change, in the relationship between research universities and their industrial neighbors.

I find that employment, payroll, and average wages grow differentially faster after the Bayh-

forts. More comprehensive patent data indicate a substantial increase in university patenting after Bayh-Dole (Henderson, Jaffe, and Trajtenberg (1998); Sampat et. al. (2003)), though this increase may reflect higher production of innovation, increased attention to commercialization of innovation, or both. By showing differential industry growth around universities after the law relative to before, my results shed light on the impact of the change brought by Bayh-Dole. 
Dole Act in industries more closely related to the technological strengths of nearby universities. The magnitudes - 31 employees and $\$ 1.5$ million in payroll per county-industry after Bayh-Dole for a standard deviation increase in industry intensity, or 13 employees and $\$ 665$ thousand in payroll per effective patent - are considerable and grow with geographical proximity to the university, supporting the importance of spatial relationships in the spread of knowledge. Areas surrounding universities that received more federal research funding before the law was passed grow faster after the law than do others; the effect is particularly large for DOD and NIH funding.

Isolating the effects of university innovation on local industry is a fundamentally difficult task because universities have developed together with their local economies over time, influencing each other and each being influenced by similar area fundamentals. University and industrial activity are thus naturally correlated: communications technologies, for example, developed in firms like Federal Telegraph in the nascent Silicon Valley just as they were developing in Stanford University laboratories. Use of a national external shock to this system, like Bayh-Dole, and in particular one whose theoretical impact differs across geographical and technological areas, brings new identification to this long-standing measurement problem. ${ }^{4}$ This strategy assumes that the industries and places I measure to grow the fastest after Bayh-Dole weren't already on faster growth trajectories, for reasons other than university research, before the law. It is possible, however, that there were pre-existing industry growth trends that continued after Bayh-Dole and explain my effect; these cannot be measured in the LBD data because they do not stretch back far enough. ${ }^{5}$

Having shown significant employment and payroll growth effects, I investigate potential mechanisms by asking which types of establishments - entrant versus incumbent, large versus small - are most complementary with university innovation in producing employment growth. Do universities generate growth via entrepreneurs or existing powerhouses?

\footnotetext{
${ }^{4}$ Previous research has investigated the effects of university spending, as opposed to innovation, on growth. For example, Aghion et. al. (2009) use political instruments to identify the effects of state university spending on growth. Kantor and Whalley (2010) use changes in endowment spending to measure effects of university activity on local labor income. Other work by Adams (1990) measures how much productivity growth nationwide can be accounted for by stocks of knowledge stored in academic publications and finds lagged growth within scientific areas. Jaffe (1989) finds that corporate patenting in a state is related to local university research spending, controlling for industry R\&D spending. Saha and Weinberg (2010) discuss, more generally, the challenges inherent in estimating the economic benefits of science.

${ }^{5}$ Data on subsets of my sample do exist far enough back to be able to address this concern to some extent. While industry-level County Business Patterns data are suppressed too severely to be of much use, confidential data from the Census of Manufactures could be used to estimate pre-trends for industries in the manufacturing sector, but there is not enough variation in my innovation measure within manufacturing to estimate solely on that sample.
} 
While entrants may be highly innovative and have been shown to drive year-to-year employment growth economy-wide (Haltiwanger et. al. 2010), incumbents may have established relationships with universities, distribution channels, manufacturing expertise, and brand name that help to preserve their power. I find that entering establishments, rather than incumbents, drive the twenty year growth effect from universities. Multi-unit expansion - large firms opening a new establishment near the university - rather than single-unit entry accounts for $70 \%$ of employment growth from entering establishments, indicating the smaller role of entrepreneurs.

Some theories of innovation and growth further predict that innovating entrants may spur technologically advanced incumbents to compete while forcing laggards into decline, generating a bifurcated effect (Aghion et. al. (2005); Aghion et. al. (2009)). I find evidence consistent with this pattern and suggestive of creative destruction: incumbents experience more turnover in industries more closely tied to university innovation. Meanwhile, select incumbents in those industries appear to remain competitive and grow.

Like entrants, small firms - and small university spinoffs in particular - are often considered to be drivers of growth (Shane (2004a)). ${ }^{6}$ But there may be economies of scope (Arrow (1962)) or scale (Chandler (1990)) in innovation - or in translating innovation into growth via mass production and marketing of new products - that might lead large firms to be complementary to university research. I thus decompose the university growth effect into entry size categories and find that the largest establishments contribute considerably more absolute employment than do small ones. Small establishments, however, enter in larger numbers in university-tied industries and contribute substantial employment growth in proportion to initial size, lending some support to the Shane view of the importance of spinoffs.

University effects are relevant for policy on multiple levels. National intellectual property policy, such as that contained in the Bayh-Dole Act, and federal research subsidies to universities both aim to enhance economic benefits derived from universities. ${ }^{7}$ Local policy makers in particular care about the benefits that accrue to university areas. Though many public attempts to generate

\footnotetext{
${ }^{6}$ We know much, descriptively, about differences in spinoff activity across institutions and industries (DiGregorio and Shane (2003)) but less about spinoffs' systematic contribution to growth.

${ }^{7}$ Because ideas are a non-rival good that can generate increasing returns to scale, they may be privately underproduced and warrant public subsidies and/or intellectual property protection to increase the expected return to investing in discovery (Romer (1986); Jones and Romer (2009)). The U.S. government engages in both of these means of encouraging research.
} 
clusters of innovation fail at huge cost (Lerner (2009)), other evidence suggests that skilled populations play an important role in subsequent area income (Glaeser et. al. (1995); Moretti (2004)). My results emphasize the importance of universities for local growth. ${ }^{8}$

The remainder of the paper is structured as follows. Section II provides background on the Bayh-Dole Act, its effect on the incentives universities face, and how it generates a useful setting in which to study the economic effects of university innovation. Section III proceeds to develop the empirical strategy, while section IV describes the multiple data sources used in measurement. Section V presents the main results of the paper and section VI discusses associated endogeneity concerns. Section VII investigates the mechanisms through which universities stimulate growth by measuring the roles of different types of establishments, and section VIII concludes.

\section{Innovation Policy and The Bayh-Dole Act}

Historically, and through the 1960s and 70s, many American universities shied away from direct involvement in commercialization of research. Though some justified it from the perspective that patenting and licensing took knowledge out of the public domain, their avoidance was substantively rooted in a fear of political embarrassment. Patenting could compromise the university's commitment to open science, they thought, and the profit motive inherent in licensing could undermine the purity of the scientific endeavor. At Columbia University, administrators felt "it is not deemed within the sphere of the University's scholarly objectives" to hold patents (Sampat (2006)). And until the 1970s, many top universities, including Harvard, Yale, Johns Hopkins, Columbia, and the University of Chicago explicitly forbade the patenting of biomedical research.

Neither was the legal regime before the Bayh-Dole Act of 1980 supportive of commercialization. The federal government held rights to intellectual property developed in universities under federally funded research, which was a large component of total research conducted: in each year from 1972 to $1980,66-69 \%$ of university research expenditures were from federal sources. ${ }^{9}$ Researchers could

\footnotetext{
${ }^{8}$ Creating a strong university out of nothing is obviously a difficult task. Using universities as a policy tool seems more reasonable in the context of marginal research subsidies or intellectual property law.

Furthermore, whether a policy to stimulate a local economy via its university would be welfare-enhancing nationally is a separate question (Glaeser and Gottlieb (2008)). Place-making policies require more justification than just evidence of stimulative local effects. In particular, they require non-linearities in agglomeration economies: benefits of one place growing outweighing losses from another shrinking. In the case of universities and local industry growth, it may well be that firms shift operations away from other geographical areas to be close to and benefit from universities. I do not address net effects of universities on industry growth across geographic areas.

${ }^{9}$ These percentages represent averages across all universities and colleges surveyed; some institutions may have
} 
patent their innovations if they wished, but with government presumption of title, they could not keep royalties from licensing unless they negotiated a special Institutional Patent Agreement (IPA) with the granting agency. Policies regarding these agreements varied widely across agencies; as a result, any attempt on the part of a researcher to secure patent ownership and royalty rights tended to involve lawyers, negotiations, drafts of agreements, and other administrative red tape.

Certainly there were some universities involved in patenting on a smaller scale before BayhDole, but even so, they kept their commercialization activities at arm's length to avoid its direct association with the university. ${ }^{10}$ Many of these were public and land grant universities that had always been more practically oriented and responsible to their local economies (Goldin and Katz (2008)).

Debate leading up to the law focused largely on the economic issues involved: the positive externalities of public knowledge versus private incentives to innovate. ${ }^{11}$ The World War II expansion of defense $R \& D$ put substantially more money in the hands of universities and corporations and raised the stakes on patent law. The government felt that federally financed innovations should be kept in the public domain to maximize potential spillovers. Others worried that companies would not fully invest in discovery without stronger intellectual property protection allowing them to benefit from innovation developed in the course of contract R\&D. Rising uncertainty over U.S. economic competitiveness heightened the pressure to produce innovation at the highest level, unhindered by burdensome legal code. ${ }^{12}$

In December 1980, Congress passed the Bayh-Dole Act, which standardized patent policy across granting agencies and reversed the presumption of title to inventions developed under federally funded research. Whereas before, rights to any government funded innovations developed

even higher federal funding shares. The statistics were calculated from data in the NSF Survey of Research and Development Expenditures at Universities and Colleges.

${ }^{10}$ There were two prominent means by which universities patented in this period. The first was to contract with the Research Corporation, an independent institution which administered patents of a number of universities. The second was to establish a research foundation only loosely affiliated with the university, a good example of which is the Wisconsin Alumni Research Foundation (WARF), which had already administered a significant number of patents before Bayh-Dole.

${ }^{11}$ The nature of this debate might lead one to think that Bayh-Dole would provide a natural setting in which to test the economic effects of IP protection relative to open science, in the spirit of Murray and Stern (2007), Aghion et. al. (2009), and Williams (2011). However, becuase the Federal government did not actively publicize the IP to which it had rights before Bayh-Dole, and commercialized only a small portion of it, the pre-1980 IP regime is likely not appropriately representative of "open science," leaving no useful counterfactual for such a test of IP rights, per se.

${ }^{12}$ University lobbyists were also involved in the debate but were by no means the focus. Much of the debate was centered on contracting firms, as discussed above, and witnesses from both universities and small businesses appeared in the hearings. 
in universities accrued to the government, now universities could patent, own rights to, and keep royalty revenues from these innovations. The rights came with a responsibility to actively promote the inventions' commercialization and satisfy a number of other simple criteria, including granting the federal government a non-exclusive license and sharing any royalties with the inventor. Further strengthening the rights of universities, Congress passed the Patent and Trademark Clarification Act in 1984, which removed some restrictions on the types of inventions universities could own and on the transfer of property rights to other parties. Together, these laws significantly strengthened the incentives of universities and faculty to produce, patent, and commercialize innovation.

Universities and faculty responded to these new incentives. ${ }^{13}$ Though some universities housed technology transfer offices to administer patents before Bayh-Dole, others opened these units at much higher rates in the mid 1980s and through the early 1990s (Figure 1). Patenting from universities rose correspondingly (Henderson, Jaffe, and Trajtenberg (1998)), with the sharpest increase beginning in the late 1980s as university infrastructure adjusted to handle faculty disclosures, patent applications, and licensing on a large scale (Figure 2). While only 55 universities had been granted a patent in 1976, 340 universities had been granted at least one patent by 2006. ${ }^{14}$ Although it is difficult to say whether faculty responded by producing more innovation after Bayh-Dole, since it's possible that existing innovation simply wasn't patented at high rates beforehand, there is evidence from the 1990s that faculty respond to stronger royalty incentives by producing higher quality innovation (Lach and Schankerman $(2008))^{15}$.

Thus in terms of both underlying culture and explicit incentives, the Bayh-Dole Act marked a great shift in the relationship between universities and industry. With congressional endorsement banishing much of the remaining hesitation to engage in patenting and licensing, these activities ceased to be political embarrassments and instead became testaments to a university's prestige.

\footnotetext{
${ }^{13}$ It may be that the incentives created by Bayh-Dole induced faculty to shift focus from basic to more applied research. I do not directly measure this possible behavioral change; one would need, at a minimum, measures of basic and applied research output from universities before and after the law, perhaps in the form of publications classified according to these categories. Moreover, it's not clear what one would infer from a result that there was a shift in research topics, as it's difficult to know what balance of basic versus applied research is socially optimal. Thursby and Kemp (2002) and Thursby and Thursby (2007) discuss these issues; Lazear (1997) and Thursby et. al. (2007) develop models clarifying possible behavioral effects generated by licensing and funding incentives. Azoulay et. al. (2007) find that, among life scientists, patents tend to go along with a flurry of academic publications, suggesting that even if research does become more applied, it's still basic enough to be within the realm of the academic.

${ }^{14}$ Counts were calculated from NBER patent data.

${ }^{15}$ There is also suggestive evidence that patenting increased most after Bayh-Dole in lines of business which most value technology transfer via patenting and licensing (Shane 2004b).
} 
The sort of large scale technology transfer from universities that exists today would have been very difficult and likely impossible to achieve without the strengthened property rights, standardized across granting agencies, that were set into law in 1980 .

\section{Universities in the Local Economy}

Economists have long considered knowledge flows to be facilitated by face-to-face interactions between people. In 1890, Alfred Marshall wrote that in industrial clusters, "the mysteries of the trade are no mystery, but are as it were, in the air," reflecting the notion that important knowledge is often transmitted without being written down. Lucas (1988) agreed that "most of what we know we learn from other people" and argued that oral transmission of knowledge is an important part of why people cluster together in cities despite the increased costs - as in the form of higher land prices, for example - that such clustering imposes. Substantial theoretical and empirical evidence supports the notion that innovation and entrepreneurship come in large part from the mixing of ideas in localities (Glaeser et. al. (1992); Duranton and Puga (2001); Agrawal et. al. (2008)), and that use of innovation is disproportionately local (Jaffe et. al. (1993); Kerr (2010)). ${ }^{16}$ Universities are likely to be focal points of such idea flows, given evidence of their high production of ideas, their connectedness to nearby industrial activity (Jaffe (1989); Furman and MacGarvie (2007); Kantor and Whalley (2009)), and their attraction of patent citations disproportionately from local areas (Belenzon and Schankerman (2010)).

There may additionally be complementarities between codified knowledge, such as patents, and non-codified ideas or know-how that would suggest a differentially high local return to codification (Arora (1996)). These complementarities are important to consider in the context of the BayhDole Act, which increased incentives for universities to codify knowledge in the form of patents. If patents are complementary with in-person knowledge sharing, then one might expect differentially high local relative to global economic growth effects after the law. ${ }^{17}$ Alternatively, if codified and

\footnotetext{
${ }^{16}$ For more discussion and evidence of local knowledge flows, innovation, and entrepreneurship, see Marshall (1890), Chinitz (1961), Jacobs (1969), Saxenian (1994), Fallick et. al. (2006), and Simonen and McCann (2008).

${ }^{17}$ Jensen and Thursby (2001) provide theoretical grounds for complementarities of patents with in-person interactions. Hellmann (2007) explores a theoretical mechanism that may or may not result in net complementarities of patents with university-firm relationships. Belenzon and Schankerman (2009) document that some universities incur costs to promote local development objectives via local technology transfer. Gaspar and Glaeser (1998) examine the theoretical and empirical effects on cities of electronic communication, which, like codified knowledge, may complement or substitute for face-to-face interaction.
} 
non-codified knowledge are substitutes, then high patenting from universities following Bayh-Dole would be expected to have diffuse growth effects. Increased willingness on the part of universities to engage with industry, however, could produce similar local growth effects if most industry contacts are local and would be indistinguishable from complementarities as the source of growth.

But there is reason to believe that these complementarities between patents and face-to-face interactions exist and can be important in the context of universities. Evidence suggests that firm success is related to the local prevalence of top scientists in related technologies, perhaps because of their hands-on involvement (Zucker and Darby (2007)). Further effort on the part of the scientist can be necessary to develop a licensed invention into a commercializable product given the embryonic phase at which many of them are legally transferred (Jensen and Thursby (2001); Thursby and Thursby (2007)). And co-mingling patterns of university and industry scientists in some fields further suggests that much learning occurs in person even upon transfer of a codified technology (Murray (2002)). Of the large number of channels through which university innovation can diffuse to industry, a few - such as publications and conferences - do well at spreading information over great distance, while many - hiring of students and faculty, consulting, patenting, and new faculty start ups - can and do have a local bias.

Of course, innovation is not the only means through which universities may affect their local economies. Skilled workers, trained in or attracted to an area, have been shown to predict subsequent income growth (Glaeser et. al. (1995)); in particular, the presence of land grant universities generates growth via increased area skills (Moretti (2004)). ${ }^{18}$ Universities may also generate local amenities - for example, musical or artistic performances - that would attract people to the area. To the extent that these other modes of university effects are complementary with university innovation, they may be captured in my estimation. Indeed, Aghion et. al. (2009) suggest that technology is likely to be complementary with investment in skills from higher education.

To understand local industry effects of universities, one would ideally like to randomly allocate universities to locations and measure related industry activity in those locations after the universities arrived relative to before. Treating only one of two similar areas with a university would generate clearly defined treatment and control groups for comparison under the hypothesis that local effects will be differentially larger than global effects. In reality, universities exist non-randomly

\footnotetext{
${ }^{18}$ Skilled human capital also predicts higher service firm formation rates (Acs and Armington (2004)).
} 
in their locations, and areas with universities differ from those without.

To approximate the ideal experiment as well as possible in the real world, I use a shock to the spread of innovation from universities, combined with cross-sectional variation between universities in the way in which they are likely to affect their surroundings after the shock. Further, these cross-sectional differences provide variation even within-area and between affected industries such that changes in area-level economic performance can be held constant.

More concretely, I argue that the Bayh-Dole Act serves as the change after which universities relate to industry in a fundamentally different way, more eager to commercialize their research. Because universities have a different mix of research strengths, they produce innovations that feed into a different mix of industries. For example, the University of Texas at Austin, which has a top aerospace engineering department, is likely to stimulate local aerospace industries more than local pharmaceuticals, while Johns Hopkins University, which specializes in biomedical sciences, will do the reverse. As such, we are likely to see differences in growth between industries within these geographical areas.

In a measure called "industry intensity," I capture the extent to which a university's innovation is likely to stimulate each industry around it. The technology classes of the patents produced by each university, combined with a patent-industry concordance, allow me to calculate an industry intensity for each 3-digit SIC industry in the area around each university. ${ }^{19}$ I measure outcomes such as employment, payroll, and payroll per worker in each industry in each county.

Formally, this strategy amounts to estimating an equation in which an outcome $y$ in county $c$, industry $i$, and year $t$ is regressed on an indicator, $I\{a B D\}_{c t}$, equal to 1 after the Bayh-Dole Act in counties near universities, the industry intensity measure, intens $s_{c i}$, and the interaction of the two:

$$
y_{c i t}=\beta_{0}+\beta_{1}\left(\text { intens }_{c i}\right)+\beta_{2}\left(I\{a B D\}_{c t}\right)+\beta_{3}\left(I\{a B D\}_{c t} * \text { intens }_{c i}\right)+\phi_{t}+\psi_{c}+\epsilon_{c i t}
$$

The coefficient $\beta_{3}$ on the interaction term measures the differential effect of universities on high intensity relative to low intensity industries after the passage of the law relative to before. It is expected to be positive for employment and payroll outcomes if university innovation has

\footnotetext{
${ }^{19} \mathrm{I}$ describe the construction of industry intensity in more detail in the data section of the paper.
} 
stimulative effects on related industries. The effects on payroll per worker are a bit more difficult to think about theoretically because, without a measure of hours worked, it does not literally represent labor productivity. However, payroll per worker is highly correlated with value added per worker during my sample period in the U.S.: the correlation between the two in the Annual Survey of Manufacturers at the 4-digit SIC level from 1977 to 1997 is $0.66 .^{20}$ To the extent that payroll per worker reflects labor productivity, one might expect $\beta_{3}$ in that regression to be positive if university innovation generates not only more work but also more productive work in an industry. Without a more detailed model, however, there is no clear prediction for this outcome. One could imagine a decline in average labor productivity if the composition of workers needed in an industry has changed.

In practice, because I include in the regressions all counties in the nation, $I\{a B D\}_{c t}$ equals 1 after the law only for counties containing or nearby one of the innovating universities in my sample. Similarly, industries in counties not near a university are not treated with a positive industry intensity. In my main specifications I include county fixed effects, $\psi_{c}$, to control for location-specific factors and year fixed effects, $\phi_{t}$, to control for cross-industry nationwide changes over time. I also estimate specifications with industry-by-year fixed effects to control for nationwide industry-specific factors in a given year.

In addition to using cross-sectional variation in industry intensities to measure the effect of universities, I employ variation across universities in the amount of federal funding they received for research in the years before Bayh-Dole. Because the law affected patent rights specifically for inventions developed in the course of federally funded research, universities that had more funding would have had more research affected by the law. This test uses variation only across, not within, geographical areas, but it is useful in that it connects industry outcomes to monetary government inputs, both overall and for specific grant-making agencies. ${ }^{21}$

The estimated regression has a similar structure:

$$
y_{c i t}=\alpha_{0}+\alpha_{1}\left(\text { fund }_{c}\right)+\alpha_{2}\left(I\{a B D\}_{c t}\right)+\alpha_{3}\left(f_{u n d} * I\{a B D\}_{c t}\right)+\phi_{i t}+\nu_{c i t}
$$

\footnotetext{
${ }^{20}$ This correlation is calculated using the 1987 SIC version of the NBER-DES Manufacturing Industry Database, 1958-2005, publicly available for download at http://www.nber.org/data/nbprod2005.html.

${ }^{21}$ Freeman et. al. (2010) discuss at greater length the estimation of returns to R\&D spending.
} 
where outcome $y$ in county $c$, industry $i$, and year $t$ are the same as those above, fund $d_{c}$ is the sum of federal research funding received by the nearby university in 1976-1980, the five years leading up to Bayh-Dole, ${ }^{22}$ and $I\{a B D\}_{c t}$ is, as before, an indicator equalling 1 after the law for counties near universities. $\quad \phi_{i t}$ are industry-by-year fixed effects to control for nationwide changes in industryspecific performance. $\quad \alpha_{3}$ is expected to be positive if federal funding translates into industry growth via research. ${ }^{23}$

Finally, though the geographic nature of this exercise has been implicit throughout the description, I also explicitly use geography for identification of spatial differences in effects. In my main specifications, "university counties, " or those near universities, are all counties within 75 miles of the university. To zero in on the effects of proximity, I re-estimate my main regressions where only counties containing the university are said to receive their effects. An increase in the coefficient of interest when the influence of a university is narrowed suggests a larger effect on industry that is more proximate to and thus more able to interact with the university.

\section{Data}

This paper uses several data sets from distinct sources, each of which I briefly describe here.

\section{A. The Longitudinal Business Database (LBD)}

The Longitudinal Business Database (LBD) of the Census provides the outcome data I use in my analysis. ${ }^{24}$ It covers all U.S. private non-farm business establishments that file payroll taxes with the IRS from 1976 to 2005; these are establishments with at least one paid employee. For each establishment, there is information on employment as of March 12 of that year and annual payroll, as well as year of entry, year of exit, and detailed industry classification. ${ }^{25}$ My analyses

\footnotetext{
${ }^{22}$ If there are multiple nearby universities, the funding for all of them is summed.

${ }^{23}$ Note that with this specification I can't rule out the possibilities that 1) federal funding is capturing other attributes of universities that lead to growth, and/or 2) federal funding goes disproportionately to areas of the country that are growing quickly after Bayh-Dole for reasons other than the nearby university.

${ }^{24}$ More detail on the construction of the LBD can be found in Jarmin and Miranda (2002).

${ }^{25}$ Though the publicly available County Business Patterns (CBP) data set contains employment and payroll information by industry at the county level, which is the level at which I ultimately run my regressions, it lacks several crucial characteristics of the LBD. First, it censors information in small county-industry groups, a shortcoming that becomes more serious in early data years such as those before my policy change. Second, it does not allow tracking of establishments over time, precluding deeper analysis of the composition of changes that occur. Finally, there are design differences in the two datasets - in part due to corrections made using longitudinal information - that cause them to diverge.
} 
are run at the county-industry-year level, though for some analyses I use the longitudinal aspect of the data to build up from the micro level. I aggregate establishments within a county to their 3-digit SIC classification to match to patent technology classes, and I cut off my analysis in 1997, before the switch to NAICS codes is made. ${ }^{26}$ The long-run nature of my question and the increased reliability of LBD data in economic census years - those ending in 2 or 7 - lead me to employ data from the five census years between 1977 and 1997 in my main set of results.

\section{B. NBER Patent Data}

The National Bureau of Economic Research Patent Data Project provides a compiled version of publicly available data from the United States Patent and Trademark Office (USPTO) on utility patents granted between 1976 and 2006 (Hall, Jaffe, and Trajtenberg (2001)). ${ }^{27}$ The data contain year of patent application and grant, assignee, and the patent technology class, among other things. Assignees (patent owners) may be individuals, U.S. or foreign corporations, U.S. or foreign governments, hospitals, or universities. I use the subset of patents assigned to universities and university-affiliated hospitals to select my sample of innovating universities and to connect the research fields in which each university is highly innovative to the industries that may use a university's innovations. $^{28}$

As previously described, university patenting grew substantially over time, from 294 patents granted in 1976 to 2,369 granted in 1997 (Figure 2). Patenting also became more pervasive; in 1976 only 55 universities were granted patents, but 269 universities had been granted at least one patent by 1997 and 340 by 2006 .

The patent data are an important part of my estimation strategy because they provide the link between university research and the nearby industries which are likely to experience growth. I now describe in detail how I construct my county and industry specific measure of innovation.

\footnotetext{
${ }^{26}$ There exist many-to-many concordances between SIC and NAICS industry classifications, but because my analysis is long-term in nature and spans 20 years as is, marginal "after" years are unlikely to justify the noise that would be added by attempting to translate industry codes.

${ }^{27}$ The NBER patent data have been updated since the version discussed in Hall, Jaffe, and Trajtenberg (2001), which only contained patents granted through 1999. The updated data can be downloaded from the NBER patent data project website: https://sites.google.com/site/patentdataproject/Home.

${ }^{28}$ The sample I select includes all universities that produced at least 7 utility patents and all hospitals that produced at least 4 utility patents granted between 1976 and 2006, the entire period of the data. Patenting is highly concentrated among the top universities and hospitals, so for each group a cutoff was imposed where the tail of the distribution thinned significantly. For both universities and hospitals, the institutions selected produced more than $95 \%$ of patents from their institution type in this period.
} 
Constructing Industry Intensities. - To construct the measure of industry intensity, I begin with patents produced through 1985 by universities and hospitals in my sample. ${ }^{29}$ Each patent of each university is assigned a technology class by the USPTO. On their own, these technology classes are difficult for a non-specialist to interpret in terms of their significance to various industries. However, following Kerr (2008), I use a probabilistic concordance, constructed by experienced practitioners, that weights each 3-digit SIC industry (SIC-3) in terms of the probability it will use a patent with a given technology classification. ${ }^{30}$ The weights sum to one across SIC-3 industries for each USPTO technology class. The university-industry-specific intensities are thus a sum of the weights across a university's patents and within an SIC-3 industry. For counties that experience effects of multiple universities, these intensities then have to be summed across universities. The final measure is constructed according to Equation 1, where $p$ is the number of patents granted to university $u$ in technology class $n$, and $w$ is the frequency of use weight for patent class $n$ in industry $i$.

$$
\text { intens }_{c i}=\sum_{u \in c} \sum_{n} w_{i n} * p_{u n}
$$

Figure 3 presents a simple example of how to construct a university's industry intensities from a concordance. Each university ends up with an industry intensity for each of approximately 400 SIC-3s, and the university weights are summed across universities in a county as shown in Equation 1. The measure incorporates both the relative intensity (across technology classes) and the scale (number of patents) with which the university innovates in a field.

The resulting industry intensity measure indeed captures the cross-industry differences in use of university innovation that one might think it should. Examples of high intensity industries in the sample include: medical equipment (including surgical, electrotherapeutic, and x-ray); photographic equipment and opthalmic goods; machinery and tools; computers, storage, and associated

\footnotetext{
${ }^{29}$ Ideally, one would want to create a measure of industry intensity based on the pre Bayh-Dole innovation intensities of universities. The goal is to exclude possible feedback effects of industry into the research agenda. Because patenting from universities was much less common before Bayh-Dole than afterwards, using only early patents is likely to miss much of the research activity that existed. However, given plausible research lags, patents granted in 1985 would have been produced almost entirely by research initiated before Bayh-Dole. The advantage of using patents until 1985 is precision in measuring industry intensities for each university.

${ }^{30}$ This concordance updates work done by Brian Silverman and dates back to a period in the early 1990s when the Canadian patent office assigned multiple classifications to each patent upon granting. They assigned not only the technology class of the patent, but also its industry of use. Thus for each technology class there would be a distribution of industries of use from which this probabilistic concordance could be derived.
} 
equipment; communications, electronics, and semiconductors; chemicals, pesticides, pharmaceutical preparations, and diagnostic substances; and national security, aircraft, guided missile/ space vehicle parts and propulsion; small arms and ammunition; search, detection, and navigation systems and instruments. Biomedical industries are especially prevalent among high intensity industries. Low intensity industries include, for example: finance, accounting, banking, insurance, brokers; clothing retail (and some production, e.g. leather gloves and mittens); transportation and carrying services (e.g. taxi, bus, freight, USPS); administration of educational, public health, and social programs; dealers: motor vehicle, RV, boat, motorcycle; construction materials: brick, stone, sand and gravel, crushed granite.

Most of these low intensity industries are generally low-skill and probably do not use much innovation produced by universities. The one notable exception is finance. In fact, there are a number of important financial innovations that emerge from universities and are used regularly by practitioners; take as a famous example the Black-Scholes option pricing model, which was developed in academia and for which the 1997 Nobel Prize in Economics was awarded to Robert Merton and Myron Scholes. However, because financial innovations are not generally patentable, this measure of university innovation will tend not to pick up innovations used by these industries, and they will score low on industry intensity.

Finally, note that the resulting measure of industry intensity is highly skewed, as expected given 1) the high concentration of patenting among a few top universities and 2) the greater prevalence of patenting in some fields over others. The standardized version of this variable, mean zero and standard deviation 1, remains skewed; it is summarized in Table 1.

\section{NSF Federal Research Funding to Universities}

Data on federal research funding to universities from 1963 to 2007 come from the National Science Foundation's publicly available survey on Federal Science and Engineering Support to Universities, Colleges, and Non-Profit Institutions. The data contain amounts of funding by government agency, university campus, category of spending, and year. There are approximately 100 agencies and 25 departments to which they belong. ${ }^{31}$ Having the data on the university campus level, as opposed to the university level, is important for systems like the University of California that has

\footnotetext{
${ }^{31}$ Data are reported only on the level of the department until 1971.
} 
multiple innovating campuses spread widely around the state.

In addition to providing funding amounts, these data also provide geographical locations for each campus - city, state, and zip - which allow me to assign each of them latitude and longitude coordinates (to define their local areas) as well as to assign them to counties using geocoding software.

To give a sense of the funding magnitudes, in 1980 , MIT was receiving $\$ 163.2 \mathrm{~m}$ in total funds, $\$ 26.9 \mathrm{~m}$ of which came from the DOD and $\$ 27.2 \mathrm{~m}$ of which came from NIH. A much less researchintense university, Montana State University at Bozeman, was also receiving significant federal funds in 1980: $\$ 10.6 \mathrm{~m}$ total, $\$ 381 \mathrm{k}$ DOD, and $\$ 346 \mathrm{k}$ NIH. Like patents, federal funding is also highly concentrated among top universities: the top five university campuses out of over 200 in my sample attracted nearly 20\% of that group's federal funding dollars between 1976 and 1980 .

\section{Geographical Data}

My empirical analysis relies on knowing not only where universities and hospitals are, but also on knowing which counties are nearby. I use Geographic Information Systems (GIS) software to translate geographical information I have on these institutions into information that is compatible with the organization of the LBD. In particular, the software can produce approximate latitude/longitude coordinates and a "containing county" code for each \{city,state,zip $\}$ triplet. It can also produce the codes of all adjacent counties and, further, can list all counties within a specified distance.

In most of my analysis, I consider all counties having any part within a 75 mile radius of an innovating university to be "university counties." All university counties are considered to be treated both by my "industry intensity" measure of innovation and by federal funding from the nearby universities. The radius of 75 miles was selected with the goal of being inclusive in any part of the U.S. In other words, though this distance seems large for the compact places of the northeast, it can be moderate for places in the south and west. Rather than adjusting the circle size around universities by region, I use a uniform circle size nationwide and perform tests in which I adjust circle size for all parts of the country simultaneously. 


\section{E. Main Sample}

The sample that results from combining these various data sources contains observations at the county-industry-year level, where industries are 3-digit SICs and included years are the five census years during the period: 1977, 1982, 1987, 1992, and 1997. Because there are often multiple universities and hospitals in a given county or in nearby counties, each of their associated "treatment effects" - federal funding and the industry intensity measure of innovation - are summed within treated county-industries. Thus the set of counties around Harvard, Harvard hospitals, and MIT are treated by the sum of federal funding to all three institutions. Within each surrounding county, a biomedical industry, for example, would be treated by the biomedical industry intensity that is the sum of those from each of those schools. The resulting data set contains only one observation for each county-industry-year, even if that unit is treated by more than one institution. Bayh-Dole treats only university counties - counties containing or surrounding a university or research hospital - in the years after 1980, so the indicator $I\{a B D\}$ equals 1 only in those county-industry-years. Table 1 presents descriptive statistics on the main sample. ${ }^{32},{ }^{33}$

\section{Results}

\section{A. Relevant Industry Growth}

Table 2 presents the main employment results. Column 1 regresses employment on an indicator that equals 1 after Bayh-Dole in university counties, on the standardized measure of industry intensity, and on the interaction of the two. The coefficient on the interaction term indicates an increase of approximately 39 workers per county-industry after Bayh-Dole for a standard deviation increase in industry intensity. This specification includes both county and year fixed effects, so the estimate tells us that industries more closely related to the local university's innovation experienced

\footnotetext{
${ }^{32}$ Note that mins and maxes have been rounded to satisfy Census Bureau confidentiality requirements, and that medians are not disclosable.

${ }^{33}$ Note that these statistics reflect a sample with a large number of zeros for county-industry-year outcomes. There are two reasons why a county-industry-year may have zero employment and payroll but still be in the data. The first is that some industries appear in a county in some years but not in others, usually entering at some point in the 20 year period I study and then remaining. That some industries enter in certain counties and others don't, however, does not imply that no other industries could have entered. In fact, all industries that are treated by university innovation have some latent propensity to enter and we only observe the ones that cross some threshold and entered. Ignoring industries that are treated but don't enter would miss part of the treatment effect. Inclusion of these county-industries is the second reason for zeros in the data. All treated industries in university counties are included in the sample.
} 
substantially greater employment growth after Bayh-Dole than did less related industries in the same county. Column 2 adds industry-by-year fixed effects to control for national industry-specific changes. Thus the coefficient of 30.51, slightly diminished from column 1, accounts for the fact that university-related industries may be the most quickly growing ones, nationally, and it measures only the additional employment growth due to nearby university innovation. ${ }^{34}$ Column 6 presents the log specification estimated on the balanced sample of county-industries that never have zero employment. This specification thus excludes all county-industries that entered during the twenty year period and all "potential" county industries that were treated with university innovation but never entered. ${ }^{35,36}$ When the specification in column 1 is run on this sample, as shown in column 5 , the coefficient of interest is still highly positive and significant; the effect in that sample, then, is driven by large county-industries that add substantial employment in absolute terms but not enough in proportional terms to be picked up in the log specification.

Columns 3 and 4 show an increase in average establishment size for treated industries; the magnitude with industry-by-year fixed effects is nearly 2 workers per establishment per year for a standard deviation increase in industry intensity. This result is a first suggestion that there may be something about university innovation that is complementary with large establishments.

Table 3 shows analogous results for payroll outcomes. A standard deviation increase in industry intensity generates an additional $\$ 1.83$ million in payroll per county-industry after BayhDole (column 1), and allocating this payroll across workers gives a $\$ 222$ increase in pay per worker for a standard deviation increase in industry intensity (column 3). Though the payroll per worker effect is not significant when industry-by-year effects are added and coefficients are averaged across the four census years following Bayh-Dole $(1982,1987,1992,1997)$, it is significant by 1997 even with the additional fixed effects (Table 4, column 6). For a standard deviation increase in industry intensity, the 20 year effect on payroll per worker is $\$ 342$ with county and year fixed effects and $\$ 208$ with industry-by-year fixed effects added. To the extent we believe payroll per worker may reflect

\footnotetext{
${ }^{34}$ In particular, the existence of a strong effect in this specification rules out the notion that the university effect I measure is driven by a non-universtiy-related, nationwide boom in biomedical industries.

${ }^{35}$ See the data section for a more complete discussion of zeros in the sample.

${ }^{36}$ These two omissions have opposite effects on the coefficient: excluding entrants makes the coefficient smaller, but excluding potential entrants makes the coefficient larger. The intuition for these effects is that the former group are treated industries that experienced substantial employment gains (from zero to positive employment), while the latter are treated industries that experienced no employment gains at all.
} 
labor productivity ${ }^{37}$ this result suggests an increase in average labor productivity in industries that more heavily use university innovation.

For both employment and payroll outcomes, effect sizes seem to rise over time after Bayh-Dole and flatten out by 1992 and 1997 (Table 4 and Figure 4). This slow adjustment to a steady state makes sense given the gradual pace with which universities altered their infrastructures to the new commercialization regime after the Act. They opened technology transfer offices at low rates in the early 1980s and at very high rates in the late 80s and early 90s (Figure 2). Without these offices, most researchers would not be bothered to initiate a long and elaborate process of patenting and licensing a discovery. But with these offices in place, patenting from universities shot up in the late 80 s and early $90 \mathrm{~s}$. The increase in employment growth in related industries at that time likely reflects this somewhat delayed but growing connectedness of universities to industry.

The total 20 year effect of university innovation on employment growth is large when compared with the base employment of 100 workers per county-industry in university counties. Taking the 1997 estimate from column 2 of Table 4, the increase of 34 workers for a standard deviation increase in industry intensity comprises a 34\% increase for industries that more intensely use the local university's innovation. When this change is viewed relative to the standard deviation of 20 year employment growth, it looks much smaller: $34 / 740=5 \%$. The large standard deviation is due to the skewness of the data; some very large county-industries raise the measure of dispersion. Another way of scaling the coefficient is per university patent affecting an industry; with this metric, the magnitude of the 20 year effect is about 15 workers per patent.

All results thus far have been estimated under the assumption that all counties within a 75 mile radius of a university are treated by it. To understand the role of proximity to the university in the extent to which industry is stimulated, I now alter that assumption and limit the reach of university treatment only to counties containing universities. Estimates for the same basic equations, but with the narrowed treatment, are displayed in row 1 of Table 5. Estimates using the 75 mile circle treatment are reproduced in row 2 for comparison. Effects sizes are significantly greater when the focus of the estimation is narrowed around university campuses: in specifications with county and year fixed effects, for a standard deviation increase in industry intensity, employment rises by

\footnotetext{
${ }^{37}$ Payroll per worker does not directly measure labor productivity because it does not account for hours worked. However, payroll per worker is correlated 0.66 with value added per worker at the SIC4 level from 1977-1997 in the Annual Survey of Manufacturers.
} 
68 workers per county-industry in "containing" counties but only by 39 workers in all "75 mile circle" counties. There is also a greater positive effect on number of establishments in containing counties and a smaller increase in average establishment size. These last two effects could reflect increased small establishment start-up activity in the areas immediately surrounding universities. All of these differences in estimates between rows 1 and 2 indicate different treatment effects of high intensity versus low intensity industries within a county depending on how close that county is to the university. This evidence suggests that proximity is important in the spread of knowledge.

The amount of people to talk to and learn from in a place also appears to facilitate the spread of knowledge. Table 6 shows that the effect of university innovation scales with initial county employment. 1977 county employment here is measured in thousands of workers, so the coefficient in column 1 indicates that an additional 100,000 initial workers corresponds to an additional 17 workers from a standard deviation increase in university innovation. The effect of universities on payroll and average establishment size also scales with initial county size.

\section{B. Differential Growth by Pre Bayh-Dole Federal Funding Levels}

Results shown thus far use the scale and relative intensity of university innovation in different technological areas as the source of cross-sectional variation. I now turn to estimating the effect of universities on local employment growth using a different source of variation: the amount of federal research funding received by university campuses in the five years before Bayh-Dole. Universities that received more funding before the law was passed would have had more research suddenly opened to commercialization, and the areas around them might be expected to experience a larger stimulative effect.

Table 7 presents estimates using total federal funding, total Department of Defense (DOD) funding, and total National Institutes of Health (NIH) funding. The latter two subcategories may track more closely dollars for practical research likely to influence industry. Indeed, the coefficients on the interaction term - the product of an indicator equalling one after Bayh-Dole and the five year pre-Bayh-Dole sum of funding - are all positive and significant, with stronger effects for DOD and NIH funding in particular. An area that received an additional $\$ 10$ million in DOD or $\$ 7$ million in NIH funding before Bayh-Dole received an additional worker per county-industry after 1980. This effect is the average over all economic census years through 1997, so it is an average 
long-term effect of initial funding. These positive employment effects from government research spending can be taken into consideration in addition to the health and national security advances that would generally be viewed as the primary economic benefits of government spending from these agencies.

\section{Endogeneity Concerns and Robustness}

There are several endogeneity concerns to keep in mind when considering these results. The biggest concern, and the one around which the empirical strategy is designed, is the endogeneity of university research agenda to local industry activity. This concern has two sources: pre-trends and measurement.

Though the core strategy of combining a shock with cross-sectional variation aims to isolate the effect of universities on industry, it leaves open the possibility that employment was growing differentially across industries and space before Bayh-Dole in such a way that it both predicts the technological fields of university innovation and continues in a similar manner after the law. In other words, this argument is that there were pre-existing industry growth trends, not having to do with university research, that continued after Bayh-Dole and explain my effect. I cannot measure the pre-trends necessary to completely rule out this possibility using the LBD data due to its leftcensoring in the pre-Bayh-Dole period. However, for this confound to explain my result, a very particular type of differential pre-trend would need to have existed: specifically, the industries I measure to be most affected by universities would need to have been growing faster than others in that area before the law. Which industries grew quickly before the law would also need to have differed across geographical areas according to the strengths of the nearby university.

One might also be concerned that my measure of industry intensity, which provides betweenindustry identification, picks up endogenous research activity of universities because it uses patents granted until 1985. Ideally the measure would use patents granted only until 1980 to capture innovation that was truly exogenous to the Bayh-Dole Act and its associated stronger connections between universities and industry. However, because patenting was considerably more sparse before the law, it would be difficult to accurately measure universities' innovative strengths with pre-1980 patents; using additional years of observed patent production improves measurement. Patents until 
1985 are still arguably exogenous to the biggest effects I find, which don't hit until 1992 and 1997. Furthermore, given patent application-to-grant lags of at least 2-3 years and plausible research lags, any patents granted by 1985 undoubtedly came from research projects conceived before Bayh-Dole.

The results are not driven by arbitrary estimation choices. Positive and significant effects are also present for quantile regressions at the 50th and 75th percentile. Some outliers at the top of the employment growth distribution can be removed without eliminating the effect. Removing some of the zero observations by reducing the number of "potential entrant industries" included in the data only strengthens the effect. ${ }^{38}$

An important consideration in understanding these effects is whether they are driven by a few top universities and their associated innovative clusters, or whether the university effect is found nationwide around innovative universities. To investigate this question, I re-run the estimation without two major hotbeds of innovative activity: Silicon Vally and Boston's Route 128 corridor. Excluding Massachusetts and California from the estimation sample results in only a 4 employee reduction in the 31 worker university effect per standard deviation increase in industry intensity. ${ }^{39}$ Other results are similarly little-altered by the exclusion. It appears that the local economic effects of universities are important nationwide.

The possibility that universities simply produced innovation in the nation's most quickly growing industries, such as biotech, also cannot explain the effect. Employment and payroll growth effects remain strong even when including industry-by-year fixed effects to account for nationwide changes in industry performance.

Estimation of the effects of federal funding on subsequent employment has more potential confounders because funding varies at the county, not industry, level. Thus any shocks that affect areas differently could potentially bias the result. If areas with highly funded universities also disproportionately experienced other positive economic shocks, my estimates of the funding effect would be biased upward. It could also be that areas with highly funded universities were trending differently before Bayh-Dole; if those areas were already growing faster beforehand - something I would not be able to observe in LBD data - I may attribute too much of their subsequent growth

\footnotetext{
${ }^{38}$ See section IV.E. describing the main data sample for a more complete discussion of "potential entrant industries" and accounting in estimation for entry.

${ }^{39} 31$ workers per county-industry is the coefficient from the specification with industry-by-year fixed effects in Table 2 , column 2 .
} 
to Bayh-Dole and federal research funding.

Finally, the timing of effects may raise concern that something other than universities generated this 20 year growth. ${ }^{40}$ I find the largest growth effects in 1992 and 1997, such that many years elapsed during which university-industry dynamics could have evolved. I argue, however, that the dynamic effects of stronger university-industry connections in the years after Bayh-Dole are an important part of what I seek to measure. The goal is to measure the long-run, general equilibrium effects of a major change in the relationship between universities and industry. Though some effects were apparent very soon after the law as commercialization began to rise, significantly more powerful effects came later as universities adjusted their commercialization infrastructure to the new innovation environment.

\section{Employment Growth Contributions by Establishment Type}

Do universities generate employment growth from entrepreneurs or from existing powerhouses? Numerous claims are launched regarding the important contribution of entrepreneurs - new and small firms - to job creation; SBA Administrator Karen Mills asserted in May 2010 that "small businesses create about 2 of every 3 new jobs in America each year," and "drive American innovation and competitiveness." 41 Recent empirical evidence, however, indicates that new - but not necessarily small - firms are responsible for much of the nation's year-to-year net job creation (Haltiwanger et. al. 2010). The extent to which these types of establishments, as purported innovators, drive the long-run employment growth effect from university innovation is unknown.

While entrants may be highly innovative, engendering market change at the expense of competitors, incumbents may be entrenched, in good position to fend off young firms and continue to grow. In particular, they may have established relationships with universities - useful when navigating bureaucracy and administrative hassle in technology transfer - as well as established systems for commercializing products: manufacturing expertise, distribution channels, and brand

\footnotetext{
${ }^{40}$ One might actually expect delayed industry effects of research, which takes time to produce, to disseminate, and potentially to develop further into a usable or marketable product. On a national level, in highly aggregated industries, Adams (1990) finds lags of approximately 20 years between the appearance of academic research and industry productivity gains.

${ }^{41}$ See Davis, Haltiwanger, and Schuh (1996) for a more complete collection of claims made by politicians and the Small Business Administration, among others, on the importance of small businesses in generating employment growth.
} 
name, all of which may help to preserve power. Some theories of innovation and growth further predict that innovating entrants may spur technologically advanced incumbents to compete while forcing laggards into decline, generating a bifurcated effect (Aghion et. al. (2005); Aghion et. al. (2009)). These theories stress the importance of entrants and of the weeding out of less productive incumbents.

To empirically evaluate the relative importance of incumbents versus entrants, I decompose the total twenty year growth effect from universities into three well-defined groups of establishments: 1) surviving incumbents: those that existed in 1977 and were still alive in 1997, 2) dying incumbents: those that existed in 1977 and exited before 1997, and 3) surviving entrants: those that entered after 1977 and were still alive in $1997 .^{42}$

Row 1 of Table 8 presents the results of this first dimension of decomposition. Cells in columns 1-4 contain coefficients on industry intensity in regressions predicting 1977 to 1997 employment change for the establishments in that group. Each coefficient thus represents the treatment effect of university innovation on that type of establishment. The coefficient of 43.72 in column 1, row 1 is the total 20 year growth effect for a standard deviation increase in industry intensity. ${ }^{43}$ Moving across columns in the top row, one can see that the entrants, with a coefficient of 46.26 (column 4, row 1), dominate incumbents in contributing to the total growth effect; the coefficients for the two incumbent groups, 19.66 and -22.2 , sum to essentially 0 net incumbent growth. The negative coefficient for dying incumbents indicates that among existing establishments, those in industries more closely connected to university innovation actually shed more employment than did others. Taken together, these results suggest a "creative destruction" effect in these innovative industries, consistent with the Aghion et. al. models. Some incumbents may respond to new competition by innovating and growing while others, perhaps the less efficient establishments, are forced out.

Not all entering establishments fit our standard notion of small entrepreneurial ventures, however. While some entering establishments are single-unit firms - i.e. the entering establishment is an entering firm - others are expansions of existing multi-unit firms. Table 9 decomposes the entering establishment effect into that from single-unit entry versus multi-unit expansion. Row 1 indicates

\footnotetext{
${ }^{42}$ Establishments that both entered and exited during the period did not contribute to the net effect and are omitted from this part of the analysis.

${ }^{43}$ This is the coefficient from a regression of (emp97 - emp77) on industry intensity with county and year fixed effects but no industry-by-year fixed effects.
} 
that when all establishment sizes are pooled, multi-unit expansions contribute approximately 2.5 times the employment growth of single-unit entrants. Moving down each column, the pooled effects are broken down by establishment size at entry to the geographic location; unsurprisingly, among small establishments, single-unit entrants drive the employment growth effect, while among large entering establishments, multi-unit expansions dominate single-unit entrants. The results of Tables 8 and 9 together indicate that the employment growth effect from university innovation is driven by entrants and in particular by large, multi-unit expansion into the areas near universities. Examples of this type of growth around universities abound, from Novartis opening a research facility in Cambridge, MA, to numerous big pharmaceutical companies establishing facilities around the University of Pennsylvania and its hospitals.

How small versus large firms, more generally, figure into the dynamics of innovating industries is also a subject of considerable theoretical and empirical focus. Small firms, and university spinoffs in particular, are often considered to be drivers of growth (Shane (2004a)), but their systematic impact on the economy is uncertain because it is difficult to track firms that use university ideas and to measure their importance relative to other firms. Small firms, and the inventors within them, may have the advantage of freedom to explore new and risky ideas (with potentially high payoffs) that large firms may avoid in favor of focusing on more immediate market rewards, potentially by buying innovations of known quality from outside the firm (Acemoglu (2009)). On the other hand, large firms may be better positioned to translate university innovation into economic growth given possible economies of scope (Arrow (1962)) or scale (Chandler (1990)) in innovation. In particular, large firms with many lines of business may be better able to self-insure against the riskiness of a new project or to use their vast resources to mass produce and market a newly developed or purchased product. It is an empirical question whether small or large firms are more complementary to universities in generating growth from research.

The rows of Table 8 further decompose each group of incumbents and entrants by establishment size at entry. In columns 2 and 4, the larger establishments contribute most positively to that column's total employment growth effect. The suggestion that large establishments are complementary with university innovation is consistent not only with the broader theories discussed above, but also with anecdotal evidence from technology transfer officers that, while small firms often license and develop a technology initially, they then pass it off to large firms to be mass-produced 
and marketed. Large firms may be better equipped to exploit relatively developed university innovation and translate it into employment growth. Scientists, too, indicate that they often go directly to large firms with their discoveries, as large firms may be more able to incorporate new methodologies or research projects. The large firm advantage may include elements of both scale and scope.

Somewhat at odds with the conventional wisdom on small business and university spinoffs, small establishments treated by universities in these data contribute much less to absolute employment gains over the 20 year period than do large establishments. The smallest establishments, however, do contribute considerably in proportion to initial size; the treatment effect for a standard deviation increase in industry intensity of 6.24 employees for surviving entrants of the smallest size is much larger relative to their 1-25 employee base than is 24.50 relative to a 1000 employee base (Table 8, column 4, rows 2 and 5). Innovation-intense industries also experience entry of significant numbers of small establishments; column 5, which regresses the number of establishments in each group that entered since 1977 and survived until 1997 on industry intensity, indicates that a standard deviation increase in industry intensity generates an additional third of a small establishment (0.36) that entered and survived but one one-hundredth (0.01) of a large entering establishment that survived to the end of the period. Entering small establishments may thus play an important role in the innovation economy even if they are not the dominant contributers to the university employment growth effect.

\section{Conclusion}

I measure the effects of university innovation on local employment and payroll growth using a new identification strategy and detailed data, which allow tight geographical and technological links between universities and industry outcomes. I find that employment, average establishment size, payroll, and payroll per worker grew differentially more after the Bayh-Dole Act of 1980 in

industries more closely related to innovation produced by the local university or hospital. My best estimate of the total employment growth effect from universities over the 20 year period from 1977 to 1997 is approximately 34 workers per county-industry for a standard deviation increase in industry intensity, or 15 workers per county-industry per effective patent, off a base of about 100 
workers per county-industry. The impact of universities increases with proximity to a university and with initial county size, supporting the importance of spatial relationships in the flow of knowledge. Overall, these results indicate the that the increase in university connectedness to industry under the new intellectual property regime created by Bayh-Dole produced important local economic benefits. The local nature of the effects reflects some combination of 1) changing university attitudes towards disseminating research to industry contacts, which may tend to be disproportionately local, and, 2) complementarities between codified (patented) and non-codified (oral) knowledge.

Federal funding of university research is also important in stimulating local employment growth: an additional $\$ 10$ million of DOD funding or $\$ 7$ million of NIH funding to universities in the five years before Bayh-Dole generated an additional worker per county-industry after 1980. Local growth effects are only one of multiple economic benefits that may be used to evaluate the large amounts of federal money - $\$ 6.2$ billion in 1971 and $\$ 23.8$ billion in 2007 - devoted to university research in the sciences. ${ }^{44}$ And of course, such local employment effects from NIH and DOD spending may still be small compared to the primary benefits in health or national security, for example, that come from associated knowledge advancement.

The mechanisms through which local university effects operate have both intuitive and surprising components. Supporting the view of new firms as drivers of economic progress, entering establishments over the period from 1977 to 1997 more than account for the full 20 year growth effect, while incumbents have an insignificant contribution, as a whole, to growth: some die off as others compete and grow. This turnover in industries most closely tied to university innovation may reflect a sort of creative destruction induced by universities' technological progress. Somewhat at odds, however, with the common notion that small firms generate the majority of new jobs, large establishments dominate smaller establishments in contributing to the 20 year growth effect in absolute terms. Furthermore, multi-unit firm expansions rather than single-unit entrants account for the majority of employment growth from establishments entering a geographic area. Considered together with the estimated increase in average establishment size in university-related industries, these results suggest a complementarity between university innovation and large establishments in

\footnotetext{
${ }^{44}$ Funding amounts are aggregates from the NSF Survey of Federal Science and Engineering Support to Universities, Colleges, and Nonprofit Institutions, reported in 2005 dollars.
} 
generating employment growth.

Numerous underlying economic characteristics of localities, from the degree of competition between firms to job mobility to a skilled population, have been shown to affect an area's subsequent growth. ${ }^{45}$ Universities hold an important place among these factors both because of their core mission as producers and transmitters of new ideas and because of the control policy-makers may potentially wield over their operations. My evidence indicates that universities have important long-run positive growth effects on their local economies, and that these effects exhibit themselves in a somewhat more subtle way than the conventional wisdom on university spinoffs would imply.

\footnotetext{
${ }^{45}$ See, for example: Glaeser et. al. (1992), Glaeser et. al. (1995), Glaeser and Kerr (2009), Glaeser et. al. (2010), Agrawal et. al. (2010), Doms et. al. (2010), Fallick et. al. (2006), and Chen et. al. (2010) for explorations of various factors of local growth.
} 


\section{REFERENCES}

Acemoglu, Daron. 2009. "A Note on Diversity and Technological Progress," MIT Working Paper 4373.

Acs, Zoltan J. and Catherine Armington. 2004. "The impact of geographic differences in human capital on service firm formation rates," Journal of Urban Economics, 56: 244-278.

Adams, James D. 1990. "Fundamental Stocks of Knowledge and Productivity Growth," The Journal of Political Economy," 98(4): 673-702.

Aghion, Philippe, Nick Bloom, Richard Blundell, Rachel Griffith, and Peter Howitt. 2005. "Competition and Innovation: an Inverted-U Relationship," Quarterly Journal of Economics, 120(2): 701-728.

Aghion, Philippe, L. Boustan, C. Hoxby, and J. Vandenbussche. 2009. "The Causal Impact of Education on Economic Growth: Evidence from U.S.," Working Paper.

Aghion, Philippe, Richard Blundell, Rachel Griffith, Peter Howitt, and Susanne Prantl. 2009. "The Effects of Entry on Incumbent Innovation and Productivity," Review of Economics and Statistics, 91(1): 20-32.

Aghion, Philippe, Mathias Dewatripont, Fiona Murray, Scott Stern, and Julien Kolev. 2009. "Of Mice and Academics: Examining the Effect of Openness on Innovation," NBER Working Paper \#14819.

Agrawal, A., Iain Cockburn and C. Rosell. 2010. "Not invented here: creative myopia and company towns," Journal of Urban Economics, 67: .78-89.

Agrawal, A., D. Kapur and J. McHale. 2008. "How do spatial and social proximity influence knowledge flows? Evidence from patent data," Journal of Urban Economics, 64.

Arora, Ashish. 1996. "Contracting for tacit knowledge: the provision of technical services in technology licensing contracts," Journal of Development Economics, 50: 233-256.

Arrow, Kenneth. 1962. "Economic welfare and the allocation of resources for invention," in Nelson, R.E. (Ed.), The Rate and Direction of Inventive Activity. Princeton: Princeton University Press, 609-619.

Azoulay, Pierre, Waverly Ding, and Toby Stuart. 2007. "The determinants of faculty patenting behavior: Demographics or opportunities?" Journal of Economic Behavior 6 Grganization, 63: 599-623.

Belenzon, Sharon and Mark Schankerman. 2009. "University knowledge transfer: private ownership, incentives, and local development objectives." The Journal of Law and Economics, 52 (1). pp. 111144.

Belenzon, Sharon, and Mark Schankerman. 2010. "Spreading the Word: Geography, Policy and University Knowledge Diffusion," CEPR Discussion Paper 8002.

Chandler, A. 1990. "Scale and Scope," Cambridge: MIT Press.

Chen, H., Gompers, P., Kovner, A., Lerner, J., 2010. "Buy local? The geography of successful and unsuccessful venture capital expansion," Journal of Urban Economics 67 (1): 90-102. 
Chinitz, B.J. 1961. "Contrasts in agglomeration: New York and Pittsburgh," American Economic Review, 51: 279-89.

Davis, Steven J., John Haltiwanger and Scott Schuh. 1996. "Small Business and Job Creation: Dissecting the Myth and Reassessing the Facts," Small Business Economics, 8: 297-315.

DiGregorio, Dante, and Scott Shane. 2003. "Why do some universities generate more start-ups than others?" Research Policy, 32: 209-227.

Doms, Mark, Ethan Lewis, and Alicia Robb. 2010. "Local labor force education, new business characteristics, and firm performance," Journal of Urban Economics, 67: 61-77.

Duranton, Gilles, and Diego Puga. 2001. "Nursery Cities: Urban Diversity, Process Innovation, and the Life Cycle of Products," American Economic Review, 91(5): 1454-1477.

Fallick, Bruce, Charles A. Fleischman, and James B. Rebitzer. 2006. "Job-Hopping in Silicon Valley: Some Evidence Concerning the Microfoundations of a High-Technology Cluster," The Review of Economics and Statistics, 88(3): 472-481.

Freeman, Richard B., Gerald Marschke, and Andrew Wang. 2010. "Estimating the Payoff to R\&D," Working Paper.

Furman, Jeffrey L. and Megan J. MacGarvie. 2007. "Academic science and the birth of industrial research laboratories in the U.S. pharmaceutical industry," Journal of Economic Behavior $\&$ Organization, 63: 756-776.

Gaspar, Jess, and Edward L. Glaeser. 1998. "Information Technology and the Future of Cities," Journal of Urban Economics, 43: 136-156.

Glaeser, Edward L., Hedi D. Kallal, Jose A. Scheinkman, and Andrei Shleifer. 1992. "Growth in Cities," The Journal of Political Economy, 100(6): 1126-1152.

Glaeser, Edward L., Jose A. Scheinkman, and Andrei Shleifer. 1995. "Economic growth in a cross-section of cities," Journal of Monetary Economics, 36(1): 117-143.

Glaeser, Edward L. and Joshua D. Gottlieb. 2008. "The Economics of Place-Making Policies," Brookings Papers on Economic Activity (Spring 2008): 155-253.

Glaeser, E., Kerr, W. 2009. "Local industrial conditions and entrepreneurship: how much of the spatial distribution can we explain?" Journal of Economics and Management Strategy, 18(3), 623663.

Glaeser, Edward L., William R. Kerr and Giacomo A.M. Ponzetto. 2010. "Clusters of Entrepreneurship," Journal of Urban Economics, 67: 150-168.

Goldin, Claudia, and Lawrence F. Katz. 2008. The Race Between Education and Technology, Harvard University Press.

Hall, B. H., A. B. Jaffe, and M. Trajtenberg. 2001.. "The NBER Patent Citation Data File: Lessons, Insights and Methodological Tools," NBER Working Paper 8498.

Haltiwanger, John C., Ron S. Jarmin, and Javier Miranda. 2010. "Who Creates Jobs? Small vs. Large vs. Young," NBER Working Paper 16300. 
Hellmann, Thomas. 2007. "The role of patents for bridging the science to market gap," Journal of Economic Behavior and Organization, 63: 624-647.

Henderson, Rebecca, Adam B. Jaffe and Manuel Trajtenberg. 1998. "Universities as a Source of Commercial Technology: a Detailed Analysis of University Patenting 1965-1988," Review of Economics and Statistics, 80: 119-127.

Jacobs, Jane. 1969 The Economy of Cities. New York: Vintage Books.

Jaffe, A., M. Trajtenberg, and R. Henderson. 1993. "Geographic Localization of Knowledge Spillovers as Evidenced by Patent Citations," Quarterly Journal of Economics, 108:3, 577-598.

Jaffe, Adam B. (1989) "Real Effects of Academic Research," The American Economic Review, 79(5): 957-970.

Jarmin, Ron S. and Javier Miranda. 2002. "The Longitudinal Business Database," Center for Economic Studies, U.S. Census Bureau Working Paper 02-17.

Jensen, Richard, and Marie Thursby. 2001. "Proofs and Prototypes for Sale: The Licensing of University Inventions," American Economic Review, 91(1): 240-259.

Jones, Charles I. and Paul Romer. 2009. "The New Kaldor Facts: Ideas, Institutions, Population, and Human Capital," NBER Working Paper 15094.

Kantor, Shawn, and Alexander Whalley. 2009. "Do Universities Generate Agglomeration Spillovers? Evidence from Endowment Value Shocks," NBER Working Paper No. 15299.

Kerr, William R. 2008. "Ethnic Scientific Communities and International Technology Diffusion," The Review of Economics and Statistics, 90(3): 518-537.

Kerr, William R. 2010. "Breakthrough Inventions and Migrating Clusters of Innovation," Journal of Urban Economics, 67(1): 46-60.

Krugman, Paul. 1991. Geography and Trade. Cambridge: MIT Press.

Lach, Saul and Mark Schankerman. 2008. "Incentives and invention in universities," RAND Journal of Economics, 39(2): 403-433.

Lazear, Edward. 1997. "Incentives in Basic Research," Journal of Labor Economics, 15(1,2): S167-S197.

Lerner, Josh. 2009. The Boulevard of Broken Dreams: Why Public Efforts to Boost Entrepreneurship and Venture Capital Have Failed - and What to Do About It. Princeton: Princeton University Press.

Lucas, Robert E. Jr. 1988. "On the Mechanics of Economic Development," Journal of Monetary Economics, 22: 3-42.

Marshall, A. 1890. Principles of Economics. London: Macmillan.

Moretti, Enrico. 2004. "Estimating the social return to higher education: evidence from longitudinal and repeated cross sectional data," Journal of Econometrics, 121: 175-212. 
Mowery, David C. and Arvids A. Ziedonis. 2000. "Numbers, Quality, and Entry: How Has the Bayh-Dole Act Affected U.S. University Patenting and Licensing?" Innovation Policy and the Economy, 1: 187-220.

Mowery, David C, Richard R. Nelson, Bhaven N. Sampat, and Arvids A. Ziedonis. 2001. "The growth of patenting and licensing by U.S. universities: an assessment of the effects of the Bayh-Dole act of 1980," Research Policy, 30: 99-119.

Mowery, David C., Richard R. Nelson, Bhaven N. Sampat, Arvids A. Ziedonis. 2004. Ivory Tower and Industrial Innovation: University-Industry Technology Transfer Before and After the BayhDole Act. Stanford: Stanford University Press.

Murray, Fiona. 2002. "Innovation as co-evolution of scientific and technological networks: exploring tissue engineering," Research Policy, 31: 1389-1403.

Murray, Fiona, and Scott Stern 2007. "Do Formal Intellectual Property Rights Hinder the Free Flow of Scientific Knowledge?: An Empirical Test of the Anti-Commons Hypothesis," Journal of Economic Behavior \&5 Organization, 63(4): 648-687.

Romer, Paul M. 1986. "Increasing Returns and Long-Run Growth," The Journal of Political Economy, 94(5): 1002-1037.

Saha, Subhra B., and Bruce A. Weinberg. 2010. "Estimating the Indirect Economic Benefits from Science," Working Paper.

Sampat, Bhaven N., David C. Mowery, and Arvids A. Ziedonis. 2003. "Changes in university patent quality after the Bayh-Dole act: a re-examination," International Journal of Industrial Organization, 21: 1371-1390.

Sampat, Bhaven N. 2006. "Patenting and U.S. academic research in the 20th century: The world before and after Bayh-Dole," Research Policy, 35: 772-789.

Saxenian, A. 1994. Regional Advantage: Culture and Competition in Silicon Velley and Route 128. Cambridge: Harvard University.

Seim, Katja. 2006. "An Empirical Model of Firm Entry with Endogenous Product-Type Choices," RAND Journal of Economics, 37(3): 619-640.

Shane, Scott. 2004. Academic Entrepreneurship. Northampton: Edward Elgar Publishing.

Shane, Scott. 2004. "Encouraging university entrepreneurship? The effect of the Bayh-Dole Act on university patenting in the United States," Journal of Business Venturing, 19: 127-151.

Simonen, J. and P. McCann. 2008. "Firm innovation: The influence of R\&D cooperation and the geography of human capital inputs," Journal of Urban Economics, 64: 146-154.

Thursby, Jerry G., and Sukanya Kemp. 2002. "Growth and productive efficiency of university intellectual property licensing," Research Policy, 31: 109-124.

Thursby, Jerry G., and Marie C. Thursby. 2007. "University licensing," Oxford Review of Economic Policy, 23(4): 620-639. 
Thursby, Marie, Jerry Thursby and Swasti Gupta-Mukherjee. 2007. "Are there real effects of licensing on academic research? A life cycle view," Journal of Economic Behavior $\mathcal{E}$ Organization, 63: $577-598$.

Williams, Heidi L. 2010. "Intellectual Property Rights and Innovation: Evidence from the Human Genome," NBER Working Paper \#16213.

Zucker, Lynne G. and Michael R. Darby. 2007. "Star Scientists, Innovation, and Regional and National Immigration," NBER Working Paper 13547. 
FIGURE 1

Openings of University and Hospital Technology Transfer Offices

$1967-2007$

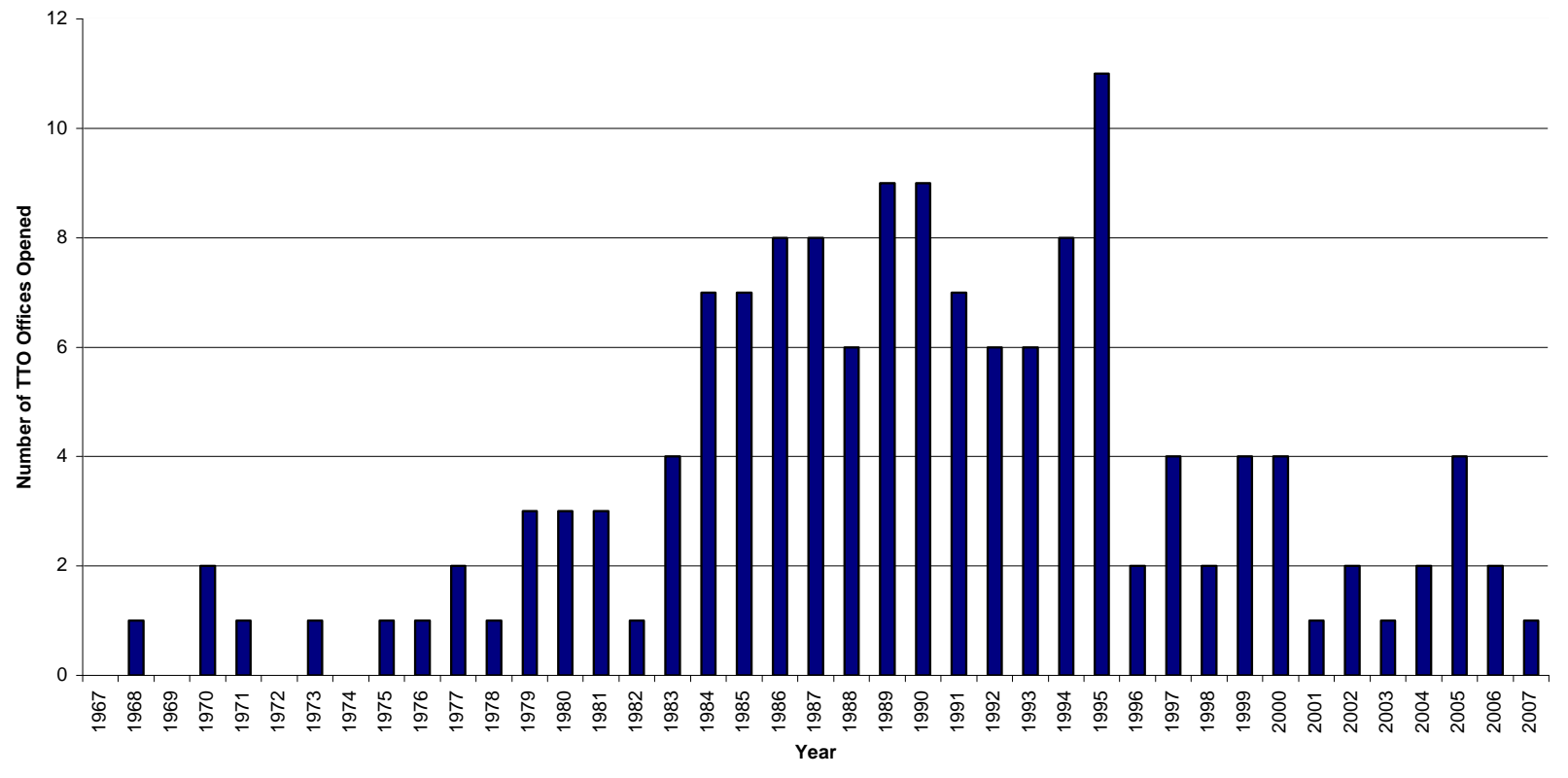

Source: Association of University Technology Managers (AUTM) Licensing Activity Survey, 2007.

Note: Bars represent the number of university technology transfer offices (among AUTM members) opened in each year from 1967 to 2007. 
FIGURE 2

University Patents Granted by Year, 1976-1997

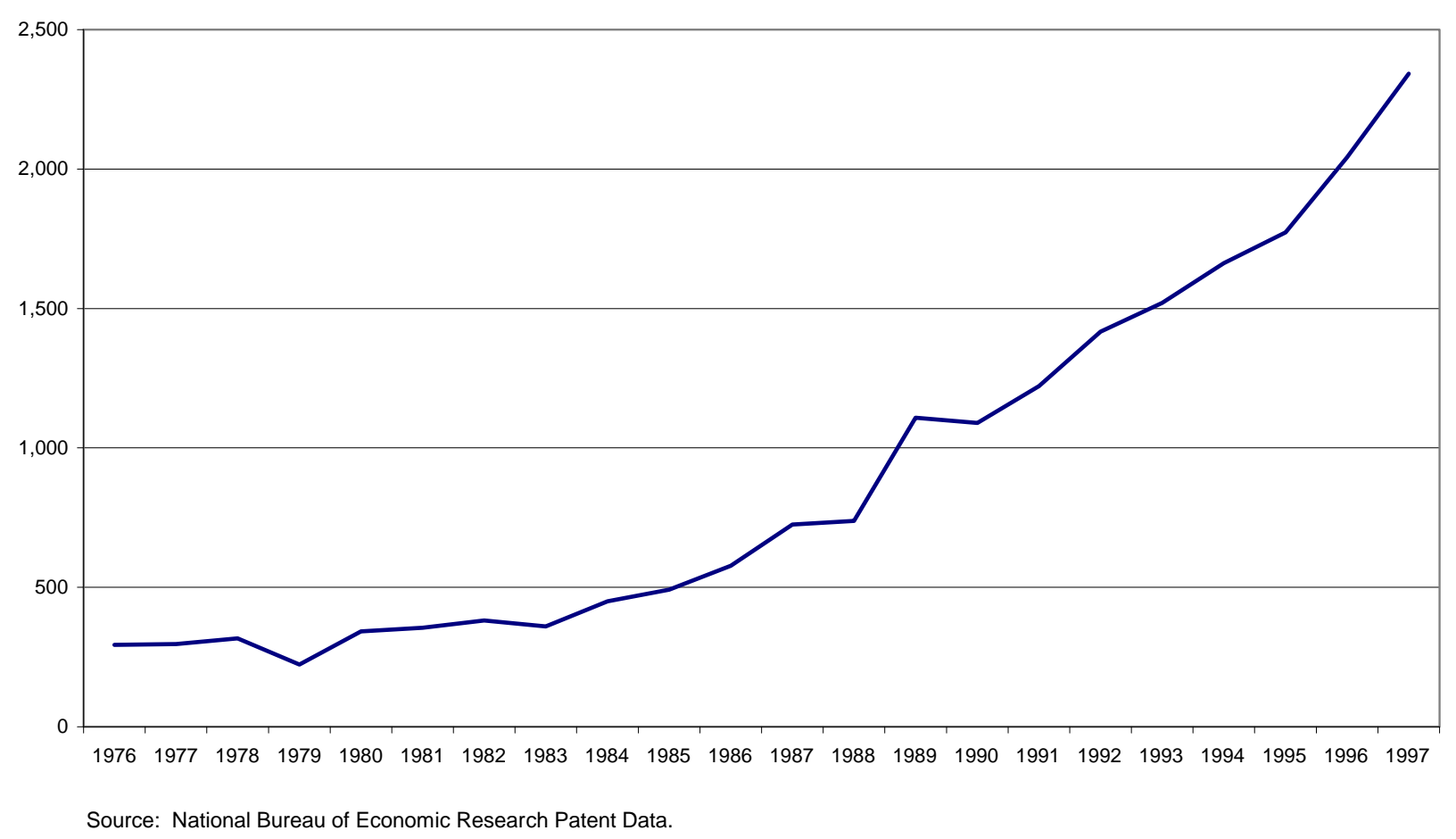


FIGURE 3

Construction of Industry Intensity from Patent Data and a Probabilistic Concordance

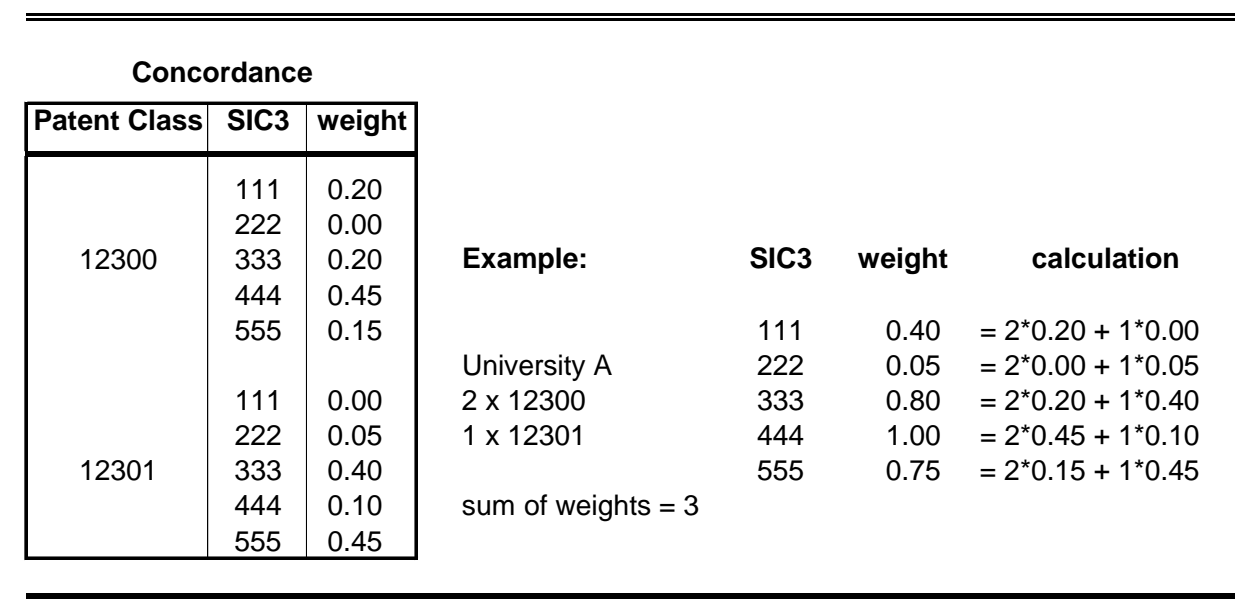

Notes:

This figure provides an example of how the industry intensity measure is constructed. The concordance on the left shows two patent classes and corresponding weights for all five SIC3 industries, even industries that have zero weight for a given patent technology class. Weights sum to 1 across SIC3s for each patent class.

If University A has two patents of the first class and one of the second, its industry intensities are calculated as shown at right. It ends up with a weight for every SIC3 industry. Because University A has 3 total patents, the sum of its industry intensities (before standardization for regressions) is 3 . Thus this measure captures both the scale and the relative intensity with which a university innovates in different technological areas. 
FIGURE 4

Employment Effects by Year After Bayh-Dole

$1982-1997$

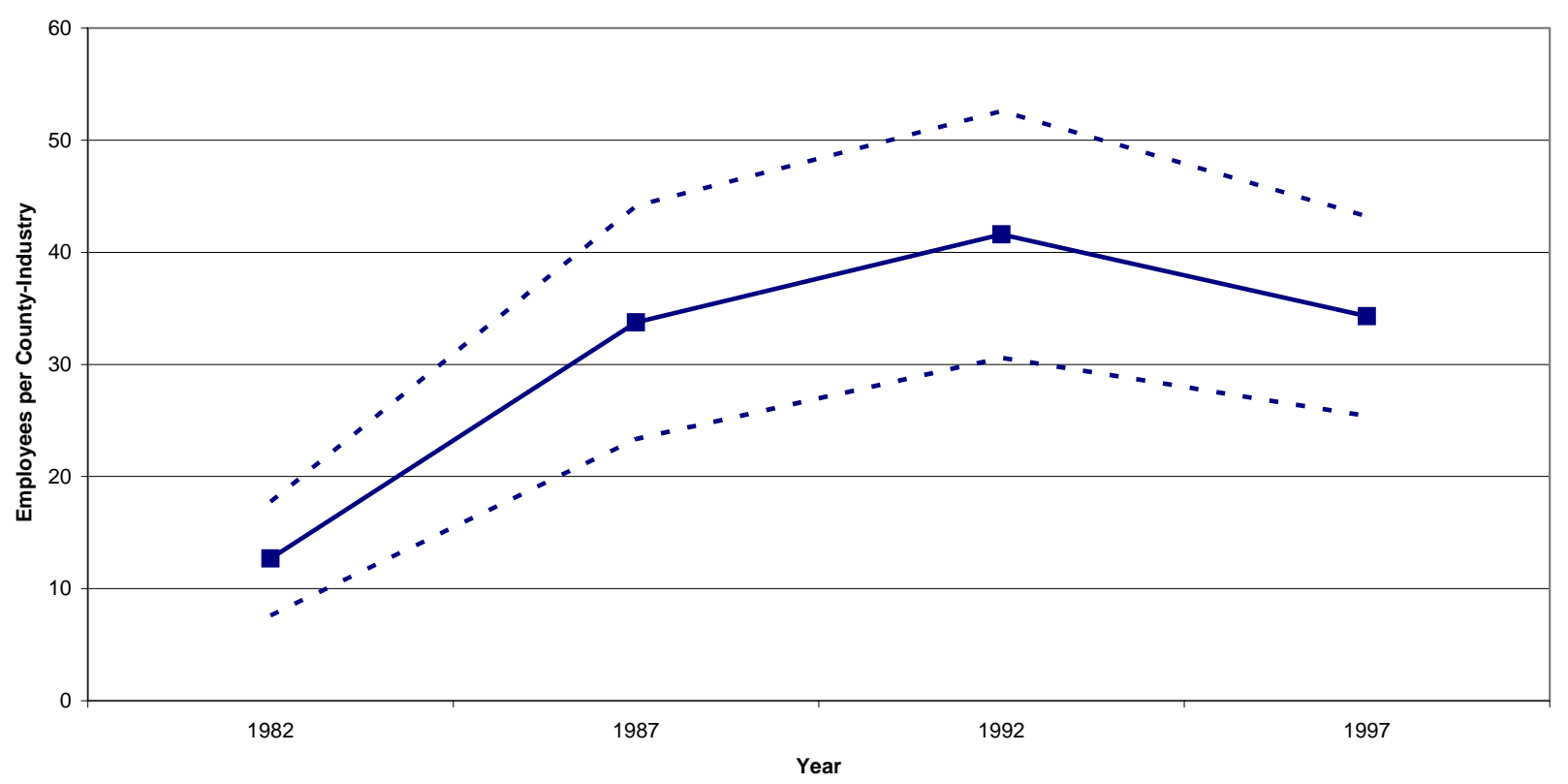

Notes: Points represent coefficients on the interaction term of industry intesity and year indicators from a regression predticting total employment in a county-industry-year, with county and industry-by-year fixed effects. Estimates for this regression are shown in Table 4, column 2. Error bands represent the $95 \%$ confidence interval around these point estimates. 
TABLE 1

Descriptive Statistics: Main Sample

\begin{tabular}{|c|c|c|c|c|c|}
\hline \multicolumn{6}{|c|}{ Panel 1: All Census Years } \\
\hline & Obs & Mean & Std. Deviation & Rounded Min & Rounded Max \\
\hline Total Employment & $4,814,860$ & 93.49 & 911.53 & 0 & 200,000 \\
\hline Total Emp, Univ Counties & $3,723,200$ & 103.77 & $1,008.72$ & 0 & 200,000 \\
\hline Total Emp, Non-Univ Counties & $1,091,660$ & 58.41 & 439.05 & 0 & 150,000 \\
\hline Employment/ \# Establishments & $4,814,860$ & 13.06 & 128.88 & 0 & 30,000 \\
\hline Total Payroll ( $\$$ thou) & $4,814,860$ & $3,131.09$ & $164,662.00$ & 0 & $280,000,000$ \\
\hline Payroll per Worker ( $\$$ thou) & $4,814,860$ & 11.02 & 438.51 & 0 & 800,000 \\
\hline Number of Establishments & $4,814,860$ & 5.01 & 40.90 & 0 & 10,000 \\
\hline Industry Intensity & $4,814,860$ & 0.00 & 1 & -0.089 & 100 \\
\hline \multicolumn{6}{|c|}{ Federal Research Funding, University Counties Only } \\
\hline 5 Yr Sum of Total Funding $(\$ \mathrm{~m})$ & $4,814,860$ & 160.52 & 326.20 & 0 & 2,400 \\
\hline 5 Yr Sum of DOD Funding (\$m) & $4,814,860$ & 16.55 & 71.16 & 0 & 600 \\
\hline 5 Yr Sum of NIH Funding (\$m) & $4,814,860$ & 62.67 & 144.18 & 0 & 950 \\
\hline \multicolumn{6}{|c|}{ Panel 2: University Counties Only } \\
\hline & Obs & Mean & Std. Deviation & Rounded Min & Rounded Max \\
\hline$\Delta$ employment (97 - 77) & 744,640 & 48.24 & 739.76 & $-70,000$ & 100,000 \\
\hline Base employment & 744,640 & 103.79 & 921.21 & 0 & 200,000 \\
\hline$\Delta \mathrm{emp}(97-77) /$ base emp & 340,837 & 0.53 & 1.35 & -2 & 2 \\
\hline \multicolumn{6}{|c|}{ Panel 3: County Level Variables } \\
\hline Total County Employment & 15,370 & $30,918.86$ & $121,380.50$ & 0 & $4,000,000$ \\
\hline Total County Employment, Univ Counties & 8,950 & $45,973.15$ & $155,172.90$ & 0 & $4,000,000$ \\
\hline Industries per County & 15,370 & 330.18 & 146.70 & 1 & 400 \\
\hline$\Delta$ county employment $(97-77)$ & 3,074 & $13,399.47$ & $46,807.55$ & $-100,000$ & 900,000 \\
\hline
\end{tabular}

Notes:

1. Observations are a county-industry-year. Panel 1 includes all five census years between 1977 and 1997. Panel 2 describes the total 1977 to 1997 change in employment.

2. Industry intensity measures the extent to which an industry is likely to be affected by innovation produced at nearby universities. It has been standardized to have mean 0 and standard deviation 1 . For details on how this variable is constructed from the technology classes of university patents, please refer to the Data section of the text.

3. Base employment is defined as the average of 1977 and 1997 employment in a county-industry.

4. Following Census Bureau rules, mins and maxes are rounded to preserve the confidentiality of establishments. 
TABLE 2

Effects of University Innovation on Related Industry Employment

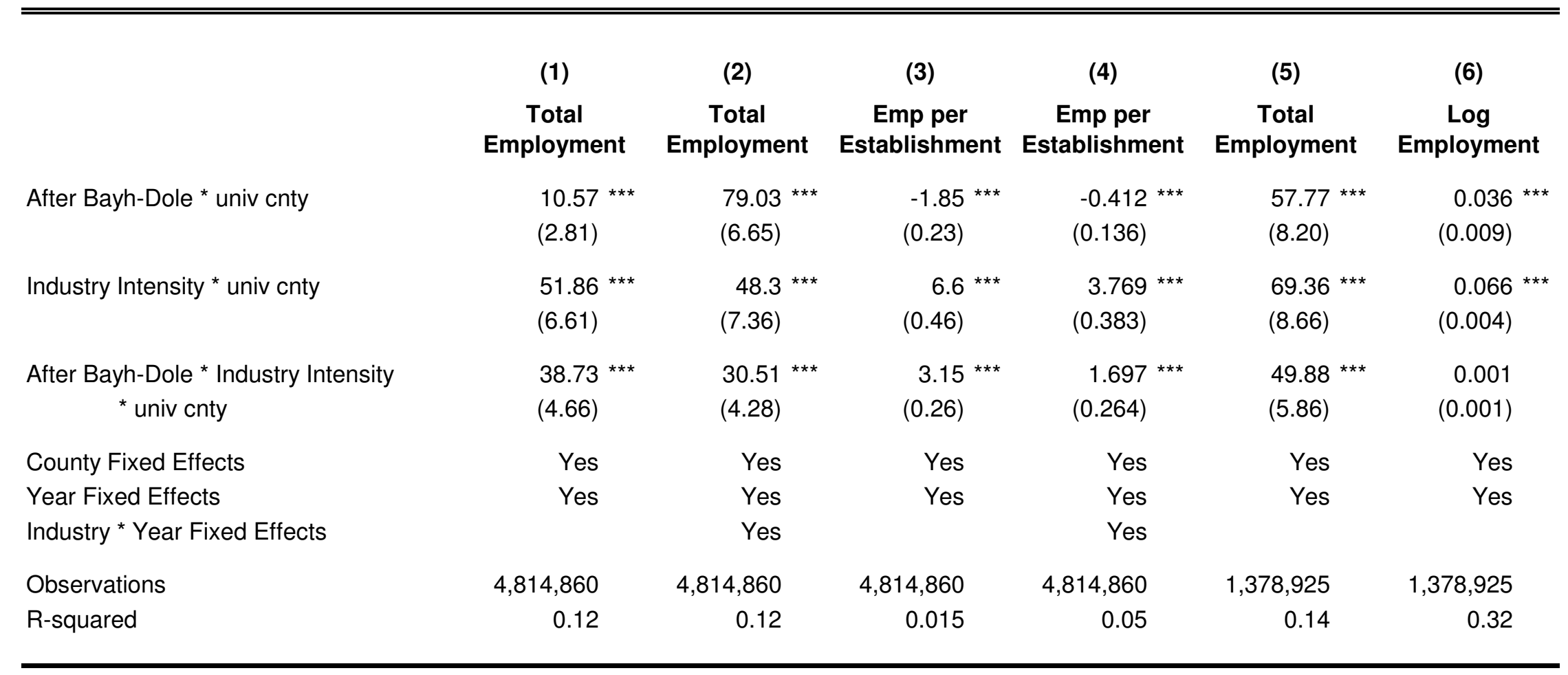

Notes:

1. Robust standard errors are clustered at the county level and adjusted for de-meaning where relevant (cols. 2 and 4 ).

2. An observation is a county-industry-year.

3. After Bayh-Dole is an indicator equal to 1 after 1980, and univ cnty is an indicator equal to 1 for counties near a university.

4. Industry intensity measures the extent to which an industry is likely to be affected by innovation produced at nearby universities. It has been standardized to have mean 0 and standard deviation 1. For details on how this variable is constructed from the technology classes of university patents, please refer to the Data section of the text.

5. Columns 5 and 6 present results from a reduced sample of just the county industries that have non-zero employment in every sample year. These specifications exclude county-industries that entered during the twenty year period and county-industries that were treated but never entered ("potential industries"). 
TABLE 3

Effects of University Innovation on Related Industry Pay

\begin{tabular}{|c|c|c|c|c|c|c|}
\hline & (1) & (2) & (3) & (4) & (5) & (6) \\
\hline & $\begin{array}{l}\text { Total Payroll } \\
\text { (\$thou) }\end{array}$ & $\begin{array}{l}\text { Total Payroll } \\
\text { (\$thou) }\end{array}$ & $\begin{array}{c}\text { Payroll per } \\
\text { Worker (\$thou) }\end{array}$ & $\begin{array}{c}\text { Payroll per } \\
\text { Worker (\$thou) }\end{array}$ & $\begin{array}{c}\text { Payroll per } \\
\text { Worker (\$thou) }\end{array}$ & $\begin{array}{l}\text { Log Payroll per } \\
\text { Worker }\end{array}$ \\
\hline After Bayh-Dole * univ cnty & $\begin{array}{l}571.45^{* \star \star} \\
(158.39)\end{array}$ & $\begin{array}{c}2287.46^{* * *} \\
(242.5)\end{array}$ & $\begin{array}{l}1.476 * * \\
(0.592)\end{array}$ & $\begin{array}{l}3.84^{* * *} \\
(0.42)\end{array}$ & $\begin{array}{l}1.684 * * \\
(0.805)\end{array}$ & $\begin{array}{l}0.051^{* * *} \\
(0.003)\end{array}$ \\
\hline Industry Intensity * univ cnty & $\begin{array}{l}1883.41^{* * *} \\
(252.39)\end{array}$ & $\begin{array}{c}1807.87^{* * *} \\
(282.5)\end{array}$ & $\begin{array}{l}0.1966^{* * *} \\
(0.041)\end{array}$ & $\begin{array}{r}0.065 \\
(0.075)\end{array}$ & $\begin{array}{r}0.001 \\
(0.031)\end{array}$ & $\begin{array}{l}0.008^{* * *} \\
(0.001)\end{array}$ \\
\hline $\begin{array}{l}\text { After Bayh-Dole * Industry Intensity } \\
{ }^{*} \text { univ cnty }\end{array}$ & $\begin{array}{l}1831.26 * \star * \\
(253.89)\end{array}$ & $\begin{array}{c}1537.34^{* * *} \\
(238.9)\end{array}$ & $\begin{array}{l}0.222^{* * *} \\
(0.038)\end{array}$ & $\begin{array}{r}0.068 \\
(0.092)\end{array}$ & $\begin{array}{l}0.314^{* * *} \\
(0.037)\end{array}$ & $\begin{array}{l}0.007^{* * *} \\
(0.001)\end{array}$ \\
\hline County Fixed Effects & Yes & Yes & Yes & Yes & Yes & Yes \\
\hline Observations & $4,814,860$ & $4,814,860$ & $4,814,860$ & $4,814,860$ & $1,378,890$ & $1,378,890$ \\
\hline R-squared & 0.0052 & 0.006 & 0.0002 & 0.0003 & 0.0019 & 0.11 \\
\hline
\end{tabular}

\section{Notes:}

1. Robust standard errors are clustered at the county level and adjusted for de-meaning where relevant (cols. 2 and 4 ).

2. An observation is a county-industry year. All five census years from 1977-1997 are included.

3. After Bayh-Dole is an indicator equal to 1 after 1980, and univ cnty is an indicator equal to 1 for counties near a university.

4. Industry intensity measures the extent to which an industry is likely to be affected by innovation produced at nearby universities. It has been standardized to have mean 0 and standard deviation 1. For details on how this variable is constructed from the technology classes of university patents, please refer to the Data section of the text.

5. Columns 5 and 6 present results from a reduced sample of just the county industries that have non-zero payroll per worker in every sample year. These specifications exclude county-industries that entered during the twenty year period and county-industries that were treated but never entered ("potential industries"). 
TABLE 4

Differential Effects by Year

\begin{tabular}{|c|c|c|c|c|c|c|}
\hline & (1) & (2) & (3) & (4) & (5) & (6) \\
\hline & $\begin{array}{c}\text { Total } \\
\text { Employment }\end{array}$ & $\begin{array}{c}\text { Total } \\
\text { Employment }\end{array}$ & $\begin{array}{c}\text { Total } \\
\text { Payroll (\$thou) }\end{array}$ & $\begin{array}{c}\text { Total } \\
\text { Payroll (\$thou) }\end{array}$ & $\begin{array}{c}\text { Payroll per } \\
\text { Worker (\$thou) }\end{array}$ & $\begin{array}{c}\text { Payroll per } \\
\text { Worker (\$thou) }\end{array}$ \\
\hline I $\{1982\}{ }^{*}$ Industry Intensity * univ cnty & $\begin{array}{l}16.81^{* * *} \\
(2.81)\end{array}$ & $\begin{array}{l}12.68^{* * *} \\
(2.59)\end{array}$ & $\begin{array}{l}337.79 * * * \\
(102.29)\end{array}$ & $\begin{array}{r}267.8^{* *} \\
(107.87)\end{array}$ & $\begin{array}{r}-0.013 \\
(0.035)\end{array}$ & $\begin{array}{r}0.126 \\
(0.086)\end{array}$ \\
\hline $\mid\{1987\}$ * Industry Intensity * univ cnty & $\begin{array}{l}40.24^{* \star *} \\
(5.54)\end{array}$ & $\begin{array}{l}33.74^{* * *} \\
(5.30)\end{array}$ & $\begin{array}{l}1680.82^{* * *} \\
(253.23)\end{array}$ & $\begin{array}{l}1426.47^{* * *} \\
(257.39)\end{array}$ & $\begin{array}{l}0.268^{* * *} \\
(0.061)\end{array}$ & $\begin{array}{l}-0.175 \\
(0.200)\end{array}$ \\
\hline I $\{1992\}{ }^{*}$ Industry Intensity * univ cnty & $\begin{array}{l}51.81^{* * *} \\
(6.00)\end{array}$ & $\begin{array}{l}41.59^{* * *} \\
(5.61)\end{array}$ & $\begin{array}{l}2481.50 * * * \\
(306.64)\end{array}$ & $\begin{array}{l}2148.63^{* * *} \\
(300.52)\end{array}$ & $\begin{array}{l}0.407^{* * *} \\
(0.046)\end{array}$ & $\begin{array}{r}0.127 \\
(0.087)\end{array}$ \\
\hline I $\{1997\}^{*}$ Industry Intensity * univ cnty & $\begin{array}{l}46.62^{* \star \star} \\
(5.07)\end{array}$ & $\begin{array}{l}34.30^{* * *} \\
(4.54)\end{array}$ & $\begin{array}{l}2858.06^{* \star *} \\
(467.03)\end{array}$ & $\begin{array}{l}2314.1^{* * *} \\
(391.06)\end{array}$ & $\begin{array}{l}0.342 \text { *** } \\
(0.095)\end{array}$ & $\begin{array}{l}0.208^{* *} \\
(0.096)\end{array}$ \\
\hline County Fixed Effects & Yes & Yes & Yes & Yes & Yes & Yes \\
\hline Year Fixed Effects & Yes & Yes & Yes & Yes & Yes & Yes \\
\hline Industry * Year Fixed Effects & & Yes & & Yes & & Yes \\
\hline Observations & $4,814,860$ & $4,814,860$ & $4,814,860$ & $4,814,860$ & $4,814,860$ & $4,814,860$ \\
\hline R-squared & 0.12 & 0.12 & 0.0052 & 0.006 & 0.0002 & 0.0002 \\
\hline
\end{tabular}

Notes:

1. Robust standard errors are clustered at the county level and adjusted for de-meaning where relevant (cols. 2 and 4 ).

2. An observation is a county-industry year. All five census years from 1977-1997 are included.

3. Industry intensity measures the extent to which an industry is likely to be affected by innovation produced at nearby universities. It has been standardized to have mean 0 and standard deviation 1. For details on how this variable is constructed from the technology classes of university patents, please refer to the Data section of the text.

4. Univ cnty is an indicator equal to 1 for counties near a university. 


\section{TABLE 5}

\section{Effects of Proximity to University Innovation}

\begin{tabular}{|c|c|c|c|c|}
\hline & $\begin{array}{c}\text { (1) } \\
\text { Total } \\
\text { Employment }\end{array}$ & $\begin{array}{c}(2) \\
\text { Total } \\
\text { Payroll } \\
\text { (\$thou) }\end{array}$ & $\begin{array}{c}\text { (3) } \\
\text { Emp per } \\
\text { Establishment }\end{array}$ & $\begin{array}{c}\text { (4) } \\
\text { Num. } \\
\text { Establishments }\end{array}$ \\
\hline $\begin{array}{l}\text { After Bayh-Dole * Industry Intensity } \\
{ }^{*} \text { univ cnty (containing cnty only) }\end{array}$ & $\begin{array}{l}67.69^{* * *} \\
(12.66)\end{array}$ & $\begin{array}{l}3243.63^{* * *} \\
(641.20)\end{array}$ & $\begin{array}{l}2.04^{* * *} \\
(0.40)\end{array}$ & $\begin{array}{l}0.202^{* *} \\
(0.083)\end{array}$ \\
\hline $\begin{array}{l}\text { After Bayh-Dole * Industry Intensity } \\
{ }^{*} \text { univ cnty (all cntys in } 75 \text { mile radius) }\end{array}$ & $\begin{array}{l}38.73^{* * *} \\
(4.66)\end{array}$ & $\begin{array}{l}1831.26 * * * \\
(253.89)\end{array}$ & $\begin{array}{l}3.15^{* * *} \\
(0.26)\end{array}$ & $\begin{array}{l}0.158^{* * *} \\
(0.032)\end{array}$ \\
\hline $\begin{array}{l}\text { County Fixed Effects } \\
\text { Year Fixed Effects }\end{array}$ & $\begin{array}{l}\text { Yes } \\
\text { Yes }\end{array}$ & $\begin{array}{l}\text { Yes } \\
\text { Yes }\end{array}$ & $\begin{array}{l}\text { Yes } \\
\text { Yes }\end{array}$ & $\begin{array}{l}\text { Yes } \\
\text { Yes }\end{array}$ \\
\hline
\end{tabular}

Notes:

1. Robust standard errors are clustered at the county level. An observation is a county-industry-year.

2. Each row in the table represents a separate regression, where the difference between the two regressions is only which counties are assumed to experience the effects of the university. The first row narrows the set of affected counties to just those containing an innovating university or hospital. The second row shows coefficients from tables 1 and 2 for comparison; all counties within a 75 mile radius of the university were assumed to be treated by the university. The indicator variable univ cnty is thus defined differently in the first and second rows.

3. After Bayh-Dole is an indicator equal to 1 after 1980 . Univ cnty is an indicator equal to 1 for counties affected by unviersities.

4. Industry intensity measures the extent to which an industry is likely to be affected by innovation produced at nearby universities. It has been standardized to have mean 0 and standard deviation 1 . For details on how this variable is constructed from the technology classes of university patents, please refer to the Data section of the text. 


\section{TABLE 6}

\section{Differential Effects of University Innovation by County Size}

\begin{tabular}{|c|c|c|c|c|}
\hline & (1) & (2) & (3) & (4) \\
\hline & $\begin{array}{c}\text { Total } \\
\text { Employment }\end{array}$ & $\begin{array}{c}\text { Employment } \\
\text { per } \\
\text { Establishment }\end{array}$ & $\begin{array}{c}\text { Total } \\
\text { Payroll } \\
\text { (\$thou) }\end{array}$ & $\begin{array}{c}\text { Payroll per } \\
\text { Worker (\$thou) }\end{array}$ \\
\hline $\begin{array}{l}\text { After Bayh-Dole * Industry Intensity } \\
\text { * univ cnty * } 1977 \text { county emp }\end{array}$ & $\begin{array}{l}0.171^{* * *} \\
(0.017)\end{array}$ & $\begin{array}{l}0.0021^{* * *} \\
(0.000)\end{array}$ & $\begin{array}{l}8.793^{* * *} \\
(0.91)\end{array}$ & $\begin{array}{r}0.0002 \\
(0.0002)\end{array}$ \\
\hline County Fixed Effects & Yes & Yes & Yes & Yes \\
\hline Year Fixed Effects & Yes & Yes & Yes & Yes \\
\hline Observations & $4,814,860$ & $4,814,860$ & $4,814,860$ & $4,814,860$ \\
\hline R-squared & 0.142 & 0.015 & 0.0063 & 0.0002 \\
\hline
\end{tabular}

Notes:

1. Robust standard errors are clustered at the county level. An observation is a county-industry-year. 2. 1977 county employment, measured in thousands of employees, is the total employment in that county in 1977.

3. After Bayh-Dole is an indicator equal to 1 after 1980.

4. Industry intensity measures the extent to which an industry is likely to be affected by innovation produced at nearby universities. It has been standardized to have mean 0 and standard deviation 1 . For details on how this variable is constructed from the technology classes of university patents, please refer to the Data section of the text.

5. Main effects of all variables are included in all specifications. 


\section{TABLE 7}

\section{Effects of Federal University Research Funding on Industry Employment}

\begin{tabular}{|c|c|c|c|}
\hline & (1) & (2) & (3) \\
\hline Dependent Variable: Employment & $\begin{array}{l}5 \text { Yr Sum: } \\
\text { Total Funding }\end{array}$ & $\begin{array}{l}5 \text { Yr Sum: } \\
\text { DOD Funding }\end{array}$ & $\begin{array}{l}5 \text { Yr Sum: } \\
\text { NIH Funding }\end{array}$ \\
\hline After Bayh-Dole * Fed Funding * univ cnty & $\begin{array}{l}0.061^{* * *} \\
(0.012)\end{array}$ & $\begin{array}{l}0.104^{* * *} \\
(0.032)\end{array}$ & $\begin{array}{l}0.140 \text { *** } \\
(0.027)\end{array}$ \\
\hline Industry * Year Fixed Effects & Yes & Yes & Yes \\
\hline Observations & $4,814,860$ & $4,814,860$ & $4,814,860$ \\
\hline R-squared & 0.11 & 0.11 & 0.11 \\
\hline
\end{tabular}

Notes:

1. Robust standard errors are clustered at the county level.

2. After Bayh-Dole is an indicator equal to 1 after 1980 , and univ cnty is an indicator equal to 1 for counties near a university.

3. Federal funding is measured in millions of dollars. The 5 year sum of federal funding includes the years 1976-1980, inclusive. Col. 2 uses the 5 year sum of funding from the Department of Defense. Col. 3 uses the 5 year sum of funding from the National Institutes of Health.

4. In all columns, the dependent variable is total employment in the county-industry-year, while the measure of federal funding changes across columns.

4. Main effects of After Bayh-Dole * univ cnty and Fed Funding * univ cnty are included in all specifications. 
TABLE 8

Decomposing the 20-Year Employment Growth Effect

by Composition Group and Establishment Size

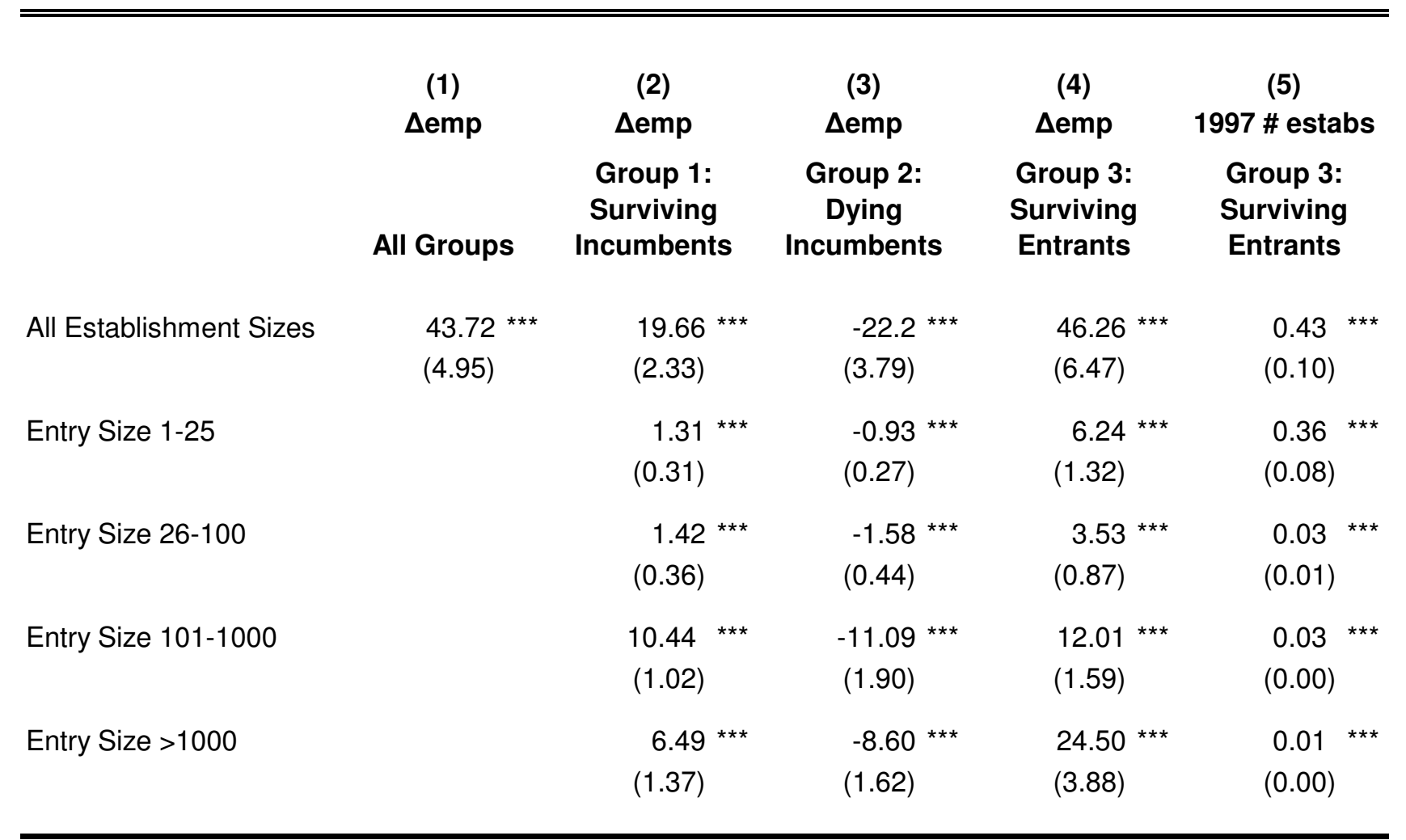

Notes:

1. Robust standard errors are clustered at the county level.

2. All cells are treatment coefficients from a regression of 1997-1977 change in employment in that groupestablishment category on industry intensity*univ cnty.

3. Industry intensity measures the extent to which an industry is likely to be affected by innovation produced at nearby universities. It has been standardized to have mean 0 and standard deviation 1 . For details on how this variable is constructed from the technology classes of university patents, please refer to the Data section of the text. 
TABLE 9

\section{Employment Growth Contribution of}

Single-Unit Entrants versus Multi-Unit Expansions by Establishment Size

\begin{tabular}{|c|c|c|c|}
\hline & $\begin{array}{c}(1) \\
\Delta \text { emp } \\
\text { Group 3: All } \\
\text { Entering } \\
\text { Establishments }\end{array}$ & $\begin{array}{c}(2) \\
\Delta \text { emp } \\
\text { Single-Unit } \\
\text { Entrants }\end{array}$ & $\begin{array}{c}(3) \\
\Delta \text { emp } \\
\text { Multi-Unit } \\
\text { Expansions }\end{array}$ \\
\hline All Sizes & $\begin{array}{l}46.28^{* * *} \\
(4.48)\end{array}$ & $\begin{array}{l}13.93^{* * *} \\
(1.68)\end{array}$ & $\begin{array}{l}32.32 \text { *** } \\
(3.63)\end{array}$ \\
\hline Entry Size 1-25 & $\begin{array}{l}6.24^{* * *} \\
(1.32)\end{array}$ & $\begin{array}{l}5.15^{* * *} \\
(1.09)\end{array}$ & $\begin{array}{l}1.09^{* * *} \\
(0.36)\end{array}$ \\
\hline Entry Size 26-100 & $\begin{array}{l}3.53^{* * *} \\
(0.87)\end{array}$ & $\begin{array}{l}2.23^{\text {*** }} \\
(0.67)\end{array}$ & $\begin{array}{l}1.30 \text { *** } \\
(0.27)\end{array}$ \\
\hline Entry Size 101-1000 & $\begin{array}{l}12.011^{* * *} \\
(1.59)\end{array}$ & $\begin{array}{l}3.24 \\
(0.56)\end{array}$ & $\begin{array}{l}8.76 \text { *** } \\
(1.10)\end{array}$ \\
\hline Entry Size $>1000$ & $\begin{array}{l}24.50 * * * \\
(3.88)\end{array}$ & $\begin{array}{l}3.31^{* * *} \\
(0.93)\end{array}$ & $\begin{array}{l}21.17^{\text {***}} \\
(3.43)\end{array}$ \\
\hline
\end{tabular}

Notes:

1. Robust standard errors are clustered at the county level.

2. All cells are treatment coefficients from a regression of 1997-1977 change in employment in that group-establishment category on industry intensity*univ cnty.

3. Industry intensity measures the extent to which an industry is likely to be affected by innovation produced at nearby universities. It has been standardized to have mean 0 and standard deviation 1 . For details on how this variable is constructed from the technology classes of university patents, please refer to the Data section of the text.

4. Entry size groups are assigned according to the size of the establishment in its year of entry. Because the data are left-censored, entry size for incumbents is defined as establishment size in 1977. 